\title{
Strategic Default, Debt Structure, and Stock Returns*
}

\author{
Philip Valta ${ }^{\dagger}$ \\ Journal of Financial and Quantitative Analysis, forthcoming
}

\begin{abstract}
This paper theoretically and empirically investigates how the debt structure and the strategic interaction between shareholders and debt holders in the event of default affect expected stock returns. The model predicts that expected stock returns are higher for firms that face high debt renegotiation difficulties and that have a large fraction of secured or convertible debt. Using a large sample of publicly traded US firms between 1985 and 2012, the paper presents new evidence on the link between debt structure and stock returns that is supportive of the model's predictions.
\end{abstract}

Keywords: Debt Structure, Debt Renegotiation, Stock Returns

JEL Classification: G13, G32, G33

\footnotetext{
${ }^{*}$ I thank Jerome Detemple, Darrell Duffie, Laurent Frésard, Amit Goyal, Alexandre Jeanneret, Diego Liechti, Erwan Morellec, Clemens Otto, Aurelie Sannajust, Enrique Schroth, Norman Schürhoff, an anonymous referee, Paul Malatesta (the Editor), and seminar and conference participants at the University of Lausanne, the 2007 Swiss Doctoral Workshop in Gerzensee, the 2008 European FMA Meetings, and the 2008 EFMA Meetings for valuable comments and suggestions. Access to the UCLA-LoPucki Research Database is gratefully acknowledged.

${ }^{\dagger}$ HEC Paris. Address: 1, rue de la Liberation, 78350 Jouy-en-Josas, France. Email: valta@hec.fr. Phone: +331396797 42. Fax: +331396770 85. Web: www.hec.fr/valta.
} 


\section{Introduction}

A firm typically defaults when shareholders are unable to make contractual payments to debt holders. Shareholders can, however, also have incentives to strategically induce default because they can sometimes recover a substantial fraction of firm value even though they are residual claimants. Recent papers explicitly consider this strategic default incentive and analyze the implications for the cross-section of stock returns (Garlappi, Shu, and Yan (2008); Garlappi and Yan (2011); Hackbarth, Haselmann, and Schoenherr (2013)), equity risk (Favara, Schroth, and Valta (2012)), and yield spreads (Davydenko and Strebulaev (2007)). While these papers provide important insights on the pricing implications of strategic default, they remain silent on how the heterogeneity of firms' debt structure affects firms' default incentives. Specifically, corporate debt often includes security provisions and conversion rights that can significantly alter shareholders' incentives to default. ${ }^{1}$ In this paper I address this issue by investigating how such covenants affect shareholders' default incentives and expected stock returns.

Shareholders have decision rights regarding the firm's policy choices and make operating decisions. To the extent that these operating decisions affect the risk of a firm's cash flow, these decisions should impact a firm's equilibrium rate of return. One important such decision is whether or not to pay interest on debt and to make debt repayments. If shareholders decide not to honor the debt contract even though they could, they default strategically. Shareholders will, however, only default strategically if they are better off in default than they would be if the firm remains a going concern. Therefore, depending on the amount of cash flow that shareholders expect to receive in default, they will decide to default strategically or not. ${ }^{2}$ Since debt structure and the possibility to renegotiate debt contracts directly affect

\footnotetext{
${ }^{1}$ The recent papers by Rauh and Sufi (2010) or Colla, Ippolitto, and Li (2013) provide evidence on the heterogeneity of firms' debt structure.

${ }^{2} \mathrm{~A}$ number of empirical papers provide evidence that shareholders receive a considerable fraction of firm value upon default. Early contributions include Gilson, John, and Lang (1990), Franks and Torous (1989),
} 
this decision to default, these characteristics should also impact firms' equilibrium rate of return.

To shed new light on the relation between debt structure and stock returns, I extend a contingent claims model by introducing secured and convertible debt. The model also allows for the renegotiation of debt contracts between shareholders and debt holders and hence permits to analyze the role of debt structure and renegotiation frictions on expected stock returns. The predictions of the model regarding renegotiation frictions and expected stock returns are consistent with the available empirical evidence (Favara, Schroth, and Valta (2012)). In addition, the model generates new predictions on the relation between secured and convertible debt and expected stock returns. More specifically, the model predicts that expected stock returns are higher for firms that have a greater fraction of secured or convertible debt. Intuitively, a large fraction of secured debt reduces the ability of shareholders to extract firm value from debt holders in renegotiation. As a result, the strategic default option becomes less valuable, and equity risk and expected stock returns increase. For convertible debt, the intuition is as follows. Because payments to convertible debt holders increase with a higher fraction of convertible debt, and debt holders delay the decision to convert, shareholders have to pay the higher coupon for a longer time. Moreover, shareholders face the risk of having to share their upside with convertible debt holders in case debt holders exercise their option to convert their claim into existing shareholders' equity. Consequently, equity risk and expected stock returns increase.

To test the model's predictions, I form a large sample of publicly traded US firms for the period 1985 to 2012. I then test the predictions using the Fama and MacBeth (1973) method and a portfolio analysis. Overall, the data are consistent with the model's predictions. First, using the normalized number of institutional shareholders as a proxy for renegotiation frictions, I find that average stock returns are increasing with renegotiation frictions, consistent with recent evidence by Favara, Schroth, and Valta (2012). As predicted by the model, and Asquish, Gertner, and Scharfstein (1994). 
this effect is stronger for firms closer to the renegotiation threshold. Intuitively, when it becomes more difficult to renegotiate the debt contract, the strategic default option becomes less valuable. As a result, shareholders will require a higher return. Second, average stock returns are increasing with the fraction of firms' secured debt. This effect is also stronger for firms closer to the renegotiation threshold, as predicted by the model. Finally, I find supporting evidence for the prediction that stock returns are increasing with the fraction of firms' convertible debt.

To provide further support for these results, I subject the main findings to a number of robustness checks. First, I address a possible endogeneity bias regarding secured and convertible debt. Second, I use an alternative proxy for renegotiation frictions. Third, I investigate average returns around Chapter 11 filings. Finally, I examine whether the results hold with alternative proxies for financial distress. Overall, the main results are robust to these additional tests.

This paper makes two contributions to the literature. First, while prior research offers important insights on the implications of bargaining in default, liquidation costs, and renegotiation frictions for stock returns and equity risk of firms with a simple capital structure (e.g., Garlappi, Shu, and Yan (2008); Garlappi and Yan (2011); Favara, Schroth, and Valta (2012); Hackbarth, Haselmann, and Schoenherr (2013)), this paper analyzes the pricing implications of more complex capital structures, including secured and convertible debt. Specifically, this study investigates how the type of debt affects expected stock returns and shows that the allocation of property rights implicit in debt covenants is important for the pricing of equity.

Second, this paper continues a line of research that generally investigates how strategic default incentives affect corporate choices and asset prices. This research relates strategic default to optimal debt structure (Berglöf and von Thadden (1994); Bolton and Scharfstein (1996); Hackbarth, Hennessy, and Leland (2007)), multiple creditors (Hege and Mella-Barral (2005)), credit spreads (Anderson and Sundaresan (1996)), dividend policy (Fan and Sundaresan (2000)), and debt and equity valuation (Mella-Barral and Perraudin (1997); Davy- 
denko and Strebulaev (2007); Garlappi, Shu, and Yan (2008); Garlappi and Yan (2011); Favara, Schroth, and Valta (2012); Hackbarth, Haselmann, and Schoenherr (2013); Zhang (2012)). In establishing a link between a firm's debt structure, debt renegotiation, and stock returns, this paper highlights the importance of breaking up firms' debt structure and proposes one specific channel relating debt structure to equity risk and expected stock returns.

The paper proceeds as follows. Section II presents the model and derives empirical predictions. Section III discusses the data and descriptive statistics. Section IV presents the main results. Section V contains robustness checks. Section VI concludes.

\section{Model and Predictions}

Corporate debt often includes features such as conversion rights or debt covenants that secure part of the debt (see, e.g., Mikkelson (1981); Leeth and Scott (1989); Rauh and Sufi (2010); Colla, Ippolito, and Li (2013)). This paper extends the contingent claims model of Fan and Sundaresan (2000) to account for this evidence, and derives testable implications on how these features relate to expected stock returns.

\section{A Model Setup}

Investment policy is fixed and managers act in shareholders' best interest. Assets are traded continuously in arbitrage free markets. The term structure is flat with risk-free rate $r$ at which investors can borrow and lend. Cash flows from operations, $X$, are independent of capital structure choices and evolve according to a geometric Brownian motion with a constant growth rate $\mu^{P}>0$ and a constant volatility $\sigma$, so that

$$
d X_{t}=\mu^{P} X_{t} d t+\sigma X_{t} d B_{t}^{P}
$$


where $B_{t}^{P}$ is a standard Brownian motion under the physical measure $P .^{3}$

The firm pays taxes $\tau \in[0,1]$ on corporate income and therefore has an incentive to issue debt. Shareholders have the option to default strategically on the firm's debt obligation, and will do so if the cash flow falls below an endogenous default (renegotiation) threshold, $X_{B}$. In default, a fraction $\alpha \in[0,1]$ of asset value is lost as a frictional cost. Because liquidation is costly, there exists a surplus associated with renegotiation, in which shareholders get a fraction $\eta \in[0,1]$ of the renegotiation surplus through Nash bargaining. ${ }^{4}$ As such, shareholders can extract rents from debt holders in renegotiation. ${ }^{5}$

Finally, to account for renegotiation frictions, I follow Davydenko and Strebulaev (2007) and assume that debt renegotiations fail with probability $q \cdot{ }^{6}$ In the case of failure, the firm is liquidated and priority rules are enforced. Debt holders receive $(1-\alpha)$ of the value of the unlevered firm in default, and shareholders receive nothing. As such, the parameter $q$ measures the likelihood of a failure of an out-of-court workout, or the possibility that a Chapter 11 reorganization is converted into a liquidation procedure according to Chapter 7 .

${ }^{3}$ Under the risk-neutral measure, $Q$, the evolution of the cash flow process, $X_{t}$, is

$$
d X_{t}=\mu^{Q} X_{t} d t+\sigma X_{t} d B_{t}^{Q}
$$

where $\mu^{Q}$ is the risk-adjusted drift, and $B_{t}^{Q}$ is a Brownian motion under the risk-neutral measure $Q$.

${ }^{4}$ Introducing proportional renegotiation costs does not change the qualitative results as long as liquidation costs are larger than renegotiation costs. Intuitively, renegotiation costs simply reduce the cash flow that is shared between shareholders and debt holders in renegotiation.

${ }^{5}$ Because debt holders give up some firm value to shareholders in renegotiation, this situation represents a deviation from the absolute priority rule; a fact which has been empirically documented (early contributions include Gilson, John, and Lang (1990), Franks and Torous (1989), and Asquith, Gertner, and Scharfstein (1994)).

${ }^{6}$ See Francois and Morellec (2004) for alternative specifcations to incorporate such frictions. 


\section{B Straight Debt}

This section considers the case of a firm with outstanding equity and straight debt. Debt payments consist of a perpetual constant coupon payment, $c$. Shareholders choose the renegotiation threshold, $X_{B}$, that maximizes the value of equity, taking into account the anticipated renegotiation outcome. This optimization problem of the shareholders yields the following Proposition (see the Appendix for details).

Proposition 1: Assume that the cash flow process evolves according to equation 1. When shareholders choose the value-maximizing renegotiation threshold, $X_{B}$, the value of equity under the risk-neutral pricing measure is

$$
E(X)=(1-\tau)\left[\left(\frac{X}{r-\mu^{Q}}-\frac{c}{r}\right)+\left(\frac{c}{r} \frac{1}{1-\lambda}\right)\left(\frac{X}{X_{B}}\right)^{\lambda}\right]
$$

the endogenous renegotiation threshold, $X_{B}$, is,

$$
X_{B}=\frac{r-\mu^{Q}}{r} \frac{\lambda}{\lambda-1} \frac{c}{1-(1-q) \eta \alpha},
$$

and $\lambda$ is

$$
\lambda=\left(\frac{1}{2}-\frac{\mu^{Q}}{\sigma^{2}}\right)-\sqrt{\left(\frac{1}{2}-\frac{\mu^{Q}}{\sigma^{2}}\right)^{2}+\frac{2 r}{\sigma^{2}}}<0 .
$$

Proposition 1 shows that the equity value in square brackets consists of two parts. The first part is the after-tax present value of cash flows to shareholders ignoring the option to default strategically. The second term captures the after-tax present value of the option to default. This option has positive value for shareholders. The term $\left(X / X_{B}\right)^{\lambda}$ is the riskneutral probability of strategic default and renegotiation.

The goal of this paper is to understand the implications of renegotiation frictions and of different types of debt for expected stock returns. In this model, the instantaneous expected 
return is a linear function of the equity beta, $\beta_{E}$, and given by

$$
E R=r+\xi \beta_{E}
$$

where $\xi=\mu^{P}-\mu^{Q}$ denotes the constant risk premium associated with the cash flow process $X$ [see, for instance, Garlappi and Yan (2011)]. If the cash flow shock is perfectly correlated with market risk, $\xi$ corresponds to the market risk premium and $\beta_{E}$ is the market beta. More generally, however, the equity beta, $\beta_{E}$, corresponds to the elasticity of the equity value with respect to the cash flow shock, $X$,

$$
\beta_{E}=\frac{\partial E}{\partial X} \frac{X}{E}=1+\frac{(1-\tau) \frac{c}{r}}{E}-\frac{(1-\tau) \frac{c}{r}}{E}\left(\frac{X}{X_{B}}\right)^{\lambda}
$$

In equation 3 , the equity beta consists of three terms. The first term is the firm's cash flow beta normalized to one. The second term measures the effect of financial leverage on equity risk. Holding everything else constant, a higher financial leverage increases the equity beta. The third term captures the equity's option value to default. This option's value increases with shareholders' ability to extract rents at the expense of creditors in renegotiation. Hence, a higher value of the default option lowers the equity beta, ceteris paribus.

I first address the question how renegotiation frictions affect expected stock returns. Differentiating $E R$ with respect to $q$ yields

$$
\frac{\partial E R}{\partial q}>0
$$

implying that more renegotiation frictions are associated with higher expected returns. The intuition for this result is as follows. If renegotiation is difficult and likely to fail, chances increase that the firm is liquidated and the absolute priority rule followed. As a result, shareholders expect to extract less firm value at the expense of debt holders in renegotiation, leading to a decrease in the equity value $(\partial E / \partial q<0)$. Consequently, shareholders have less 
incentives to default strategically and will delay their strategic default decision $\left(\partial X_{B} / \partial q<\right.$ 0). As such, renegotiation frictions make shareholders' default option less valuable. As a result, the equity beta and expected stock returns increase. Note that this prediction holds unconditionally of the firm's distance to strategic default and renegotiation. However, since the main economic effect operates through the renegotiation threshold, the model implies that the effect should be stronger for firms closer to the renegotiation threshold.

Prediction 1. Firms facing higher renegotiation frictions have higher expected stock returns. This effect is stronger for firms closer to the renegotiation threshold.

\section{Secured Debt}

Secured debt represents a large part of corporate debt and has received considerable attention in the literature. It has been argued that secured debt can increase firm value by limiting possible legal claims in bankruptcy (Scott $(1977 ; 1979)$ ) and that it reduces administrative and enforcement costs, prevents asset substitution, and alleviates the underinvestment problem (Smith and Warner (1979); Johnson and Stulz (1985)). Moreover, Morellec (2001) shows that pledging part of the firm's assets as collateral to the debt contract by issuing secured debt increases firm value.

The wide use of secured debt has also been empirically documented. Barclay and Smith (1995), for instance, document that on average one third of firms' debt is secured. Leeth and Scott (1989) report for a sample of small business loans that about sixty percent of the loans are secured by some type of collateral, and Houston and James (1996) find that about 30 percent of debt is secured. Despite the fact that firms hold a considerable fraction of secured debt, existing models remain silent on the implications of security provisions for equity risk and expected stock returns. However, the proportion of secured debt is likely to be an important determinant of what shareholders can expect to recover in debt renegotiations. In this section, I therefore consider the case of a firm with outstanding equity, straight debt, and secured debt to address this question. 
When debt is secured, debt holders require the firm to pledge a part of the firm's assets as collateral. Shareholders cannot sell the collateral or increase its risk without agreement of debt holders. Suppose that debt holders secure part of their debt with existing assets as a collateral. The contract specifies that in renegotiation, debt holders get a fraction $\pi \in[0,1]$ of the unlevered firm value for sure, while they negotiate over the residual value with shareholders. In such a setup, the amount of collateral naturally relates to the proportion of secured debt. The higher the collateral specified by $\pi$, the greater the firm's fraction of secured debt.

Denote by $X_{S}$ the endogenous renegotiation threshold in the presence of secured debt. Suppose furthermore that other frictions make renegotiations difficult. Since shareholders have no claim on the assets that are used as collateral for the secured debt, the expected value of equity in renegotiation is reduced by the fraction of the firm's secured assets. Compared with the straight debt case, shareholders receive a smaller cash flow (by $(1-\pi))$ in renegotiation, all else equal.

As in the previous section, shareholders' objective is to choose the renegotiation threshold, $X_{S}$, that maximizes the value of equity. Solving the optimization problem yields Proposition 2.

Proposition 2: Assume that the cash flow process evolves according to equation 1. When a firm has secured debt outstanding, and shareholders choose the value-maximizing renegotiation threshold, $X_{S}$, the value of equity under the risk-neutral pricing measure is

$$
E^{S}(X)=(1-\tau)\left[\left(\frac{X}{r-\mu^{Q}}-\frac{c}{r}\right)+\left(\frac{c}{r} \frac{1}{1-\lambda}\right)\left(\frac{X}{X_{S}}\right)^{\lambda}\right]
$$

and the endogenous renegotiation threshold, $X_{S}$, is

$$
X_{S}=\frac{r-\mu^{Q}}{r} \frac{\lambda}{\lambda-1} \frac{c}{1-(1-q) \eta \alpha(1-\pi)} .
$$


Moreover, the expected return is given by

$$
E R^{S}=r+\xi \beta_{E}^{S}=r+\xi\left(1+\frac{(1-\tau) \frac{c}{r}}{E^{S}}-\frac{(1-\tau) \frac{c}{r}}{E^{S}}\left(\frac{X}{X_{S}}\right)^{\lambda}\right)
$$

Note that the equity value, the equity beta, and expected stock returns are the same as in the previous section. The only difference comes from the renegotiation threshold, $X_{S}$, that now contains the additional component $(1-\pi)$ in the denominator. As such, the proportion of secured debt affects equity risk and expected stock returns only through the renegotiation threshold $X_{S}$.

Specifically, if a larger proportion of debt is secured, shareholders will be able to extract less from debt holders in a potential renegotiation. As a result, the expected equity value in renegotiation is smaller $(\partial E / \partial \pi<0)$, and shareholders will wait longer before they default strategically $\left(\partial X_{S} / \partial \pi<0\right)$. Hence, a higher fraction of secured debt reduces the ability of shareholders to extract firm value from debt holders in renegotiation and decreases the value of the strategic default option. As a result, the equity beta and expected stock returns increase with the fraction of secured debt $\left(\partial E R^{S} / \partial \pi>0\right)$. This prediction holds unconditionally of the firm's distance to strategic default and renegotiation. However, similar to renegotiation frictions, the model implies that the effect should be stronger for firms closer to the renegotiation threshold.

Prediction 2. Firms with a larger proportion of secured debt have higher expected stock returns. This effect is stronger for firms closer to the renegotiation threshold.

\section{Convertible Debt}

Corporate debt routinely incorporates conversion options, and firms with capital structures that include convertible debt claims represent a broad spectrum of firm size and industries (Mikkelson (1981)). There are numerous theoretical explanations for the use of convertible debt, including, among others, information asymmetry problems (Stein (1992)), agency costs 
(Jensen and Meckling (1976)), or the need for sequential-financing (Mayers (1998)).

A standard approach for valuing convertible debt is to decompose the convertible debt value into an investment and option component (Ingersoll (1977)). The idea behind this decomposition is that both components can be priced separately, such that the investment component is typically obtained as the value of straight debt of an appropriate benchmark firm. This practical approach, however, assumes that the conversion strategy does not affect the default strategy. Since the goal of this paper is to analyze the economic mechanism of shareholders' choice to default strategically, the interaction between debt holders' conversion strategy and shareholders' default strategy must be considered. In this section I analyze the implications of this interaction for expected stock returns and extend the straight debt model by adding convertible debt to the capital structure.

Consider a firm with outstanding equity, perpetual straight debt with coupon, cs, and perpetual convertible debt with coupon, $c c$, as long as the firm's cash flow is above the renegotiation threshold and no conversion takes place. I assume for simplicity that straight and convertible debt have the same priority. This assumption is not critical for the subsequent analysis, and other types of seniority could be incorporated leading to qualitatively similar results (Lyandres and Zhdanov (2013)). Moreover, I assume that there is no call provision, that the whole debt issue is converted at the same point in time, and that in renegotiations, the holders of convertible and straight debt are negotiating side by side against shareholders.

In this setup, shareholders will default strategically if the firm's cash flow, $X$, hits the endogenous renegotiation threshold, $X_{D}$. On the other hand, debt holders will convert their claim into a fraction $\gamma$ of equity if the firm's cash flow crosses the conversion threshold $X_{C}$. Hence, to determine the equity value, lower and upper boundary conditions are needed.

The lower value-matching condition for the value of equity in renegotiation is identical to the case of straight debt, because convertible and straight debt holders are negotiating side by side against shareholders, and therefore the expected value in renegotiations for shareholders remains unchanged (see the Appendix). Alternatively, if the cash flow crosses 
the conversion threshold, convertible debt holders loose their coupon claim, and the firm becomes a levered firm with straight debt only. Existing shareholders receive $(1-\gamma)$ of the equity value after conversion, namely $(1-\gamma) E^{\prime}\left(X_{C}\right)=(1-\gamma)\left(v^{\prime}\left(X_{C}\right)-D^{\prime}\left(X_{C}\right)\right)$, where $E^{\prime}\left(X_{C}\right)$ is the equity value at the conversion threshold right after conversion has taken place (with equity and only straight debt outstanding), $v^{\prime}\left(X_{C}\right)$ is the value of the firm right after conversion, and $D^{\prime}\left(X_{C}\right)$ is the value of straight debt right after conversion.

The proportion of convertible debt as a function of the two coupons $c c$ and $c s$ is defined as $\varphi=c c /(c s+c c)$. In this setting, the expected recovery of convertible debt holders in liquidation and renegotiation is $[\varphi q(1-\alpha)+\varphi(1-q)(1-\eta \alpha)]\left[X_{D} /(r-\mu)\right](1-\tau)$ (valuematching condition). Upon conversion, convertible debt holders obtain a fraction $\gamma$ of the value of equity at the conversion threshold right after conversion, $\gamma E^{\prime}\left(X_{C}\right)$.

Shareholders choose the renegotiation threshold, $X_{D}$, that maximizes the value of equity, taking into account the anticipated renegotiation outcome and convertible debt holders' optimal conversion strategy. Solving the optimization problem yields Proposition 3 (see the Appendix).

Proposition 3: Assume that the cash flow process evolves according to equation 1. A firm has convertible and straight debt outstanding, shareholders choose the equity valuemaximizing renegotiation threshold, $X_{D}$, and convertible debt holders choose the debt valuemaximizing conversion threshold, $X_{C}$. For $X_{D}<X<X_{C}$, the value of equity under the risk-neutral pricing measure is given by

$$
\begin{aligned}
E^{C}(X)= & (1-\tau)\left[\frac{X}{r-\mu^{Q}}-\frac{(c s+c c)}{r}\right] \\
& +A R(1-\tau)\left(\frac{X_{D}}{r-\mu^{Q}}((1-q) \alpha \eta-1)+\frac{(c s+c c)}{r}\right) \\
& +A C\left((1-\gamma) E^{\prime}\left(X_{C}\right)-(1-\tau)\left(\frac{X_{C}}{r-\mu}-\frac{(c s+c c)}{r}\right)\right),
\end{aligned}
$$


where $A R$ and $A C$ are

$$
\begin{aligned}
& A R=\left(\frac{X}{X_{D}}\right)^{\lambda_{2}} \frac{\left(X^{\lambda_{1}-\lambda_{2}}-X_{C}^{\lambda_{1}-\lambda_{2}}\right)}{\left(X_{D}^{\lambda_{1}-\lambda_{2}}-X_{C}^{\lambda_{1}-\lambda_{2}}\right)}, \\
& A C=\left(\frac{X}{X_{C}}\right)^{\lambda_{2}} \frac{\left(X^{\lambda_{1}-\lambda_{2}}-X_{D}^{\lambda_{1}-\lambda_{2}}\right)}{\left(X_{C}^{\lambda_{1}-\lambda_{2}}-X_{D}^{\lambda_{1}-\lambda_{2}}\right)},
\end{aligned}
$$

and $\lambda_{1}$ and $\lambda_{2}$

$$
\begin{aligned}
& \lambda_{2}=\left(\frac{1}{2}-\frac{\mu^{Q}}{\sigma^{2}}\right)-\sqrt{\left(\frac{1}{2}-\frac{\mu^{Q}}{\sigma^{2}}\right)^{2}+\frac{2 r}{\sigma^{2}}<0} \\
& \lambda_{1}=\left(\frac{1}{2}-\frac{\mu^{Q}}{\sigma^{2}}\right)+\sqrt{\left(\frac{1}{2}-\frac{\mu^{Q}}{\sigma^{2}}\right)^{2}+\frac{2 r}{\sigma^{2}}>0 .}
\end{aligned}
$$

The value of equity consists of three parts. The first row represents the after-tax present value of cash flows to shareholders ignoring the shareholders' option to default strategically and convertible debt holders' option to convert. The $A R$-term in the second row corresponds to the present value of a claim (barrier option) that pays one unit at a future point in time when the cash flow $X$ crosses the constant renegotiation threshold $X_{D}$ without crossing the constant conversion threshold $X_{C}$ before. Since the expression in parentheses following the $A R$-term is positive, the overall second row is positive and corresponds to the after-tax value of the option to default strategically. Accordingly, the $A C$-term in the third row represents the present value of a claim that pays one unit only if $X$ crosses the conversion threshold $X_{C}$ and no renegotiation has occurred. Since the expression in parentheses following the $A C$ term is negative, the third row is overall negative and captures the value loss to shareholders due to debt holders' option to convert their claim into equity.

As in the previous sections, the equity beta is defined as the elasticity of the equity value with respect to the cash flow shock. Hence, the equity beta and expected stock returns are 
given by

$$
\beta_{E}^{C}=\frac{\partial E^{C}}{\partial X} \frac{X}{E^{C}}=\left[\begin{array}{l}
(1-\tau) \frac{1}{r-\mu^{Q}} \\
+\frac{\partial A R}{\partial X}(1-\tau)\left(\frac{X_{D}}{r-\mu^{Q}}((1-q) \alpha \eta-1)+\frac{(c s+c c)}{r}\right) \\
+\frac{\partial A C}{\partial X}\left((1-\gamma) E^{\prime}\left(X_{C}\right)-(1-\tau)\left(\frac{X_{C}}{r-\mu^{Q}}-\frac{(c s+c c)}{r}\right)\right)
\end{array}\right] \times \frac{X}{E^{C}}
$$

and

$$
E R=r+\xi \beta_{E}^{C},
$$

where

$$
\frac{\partial A R}{\partial X}=\left(\frac{X}{X_{D}}\right)^{\lambda_{2}} \frac{1}{X} \frac{\left(\lambda_{1} X^{\lambda_{1}-\lambda_{2}}-\lambda_{2} X_{C}^{\lambda_{1}-\lambda_{2}}\right)}{\left(X_{D}^{\lambda_{1}-\lambda_{2}}-X_{C}^{\lambda_{1}-\lambda_{2}}\right)}
$$

and

$$
\frac{\partial A C}{\partial X}=\left(\frac{X}{X_{C}}\right)^{\lambda_{2}} \frac{1}{X} \frac{\left(\lambda_{1} X^{\lambda_{1}-\lambda_{2}}-\lambda_{2} X_{D}^{\lambda_{1}-\lambda_{2}}\right)}{\left(X_{C}^{\lambda_{1}-\lambda_{2}}-X_{D}^{\lambda_{1}-\lambda_{2}}\right)} .
$$

In the equity beta expression, the terms $\partial A R / \partial X$ and $\partial A C / \partial X$ are the sensitivities of the barrier options with respect to the cash flow shock, $X$, and are interpreted similarly to the delta of an option. Since the $A R$-term represents a put option, its derivative with respect to $X$ is negative. Conversely, the $\partial A C / \partial X$-term is positive like the delta of a plain vanilla call option. Overall, the second row captures the effect of shareholders' strategic default option on the equity beta. Accordingly, the third row measures the effect of debt holders' option to convert their claim into equity on the equity beta.

As noted by Hennessy and Tserlukevich (2008), endowing debt holders with an option to convert their debt into equity results in additional strategic interdependence between shareholders and debt holders. The optimal renegotiation and conversion barriers result from a Nash equilibrium between shareholders and convertible debt holders. Shareholders choose the equity value maximizing renegotiation strategy given their beliefs about the debt holders' conversion strategy. Accordingly, debt holders select an optimal conversion strategy to maximize the convertible debt value given their beliefs about shareholders' renegotiation strategy. 
These restrictions are expressed by the two smooth-pasting conditions

$$
\left.\frac{\partial E}{\partial X}\right|_{X=X_{D}}=(1-q) \eta \alpha\left(1 /\left(r-\mu^{Q}\right)\right)(1-\tau)
$$

and

$$
\left.\frac{\partial D^{C}}{\partial X}\right|_{X=X_{C}}=\gamma \frac{\partial E^{\prime}\left(X_{C}\right)}{\partial X_{C}}
$$

I obtain the optimal renegotiation and conversion thresholds by jointly solving the two smooth-pasting conditions numerically. I solve for these thresholds using the following baseline assumptions: $\alpha=5 \%, \gamma=0.1, r=6 \%, \mu^{Q}=2 \%, c s=5, \sigma=30 \%, q=0.5, \eta=0.5$ and $\tau=0.35$. In this base case environment, renegotiation fails half of the time, shareholders and debt holders have the same amount of bargaining power, and debt holders receive $10 \%$ of shareholders' equity at conversion $(\gamma=0.1)$. I have verified that the results are not sensitive to the choice of these parameter values.

Figure 1 shows how the optimal renegotiation and conversion thresholds vary with the proportion of convertible debt. Interestingly, the renegotiation threshold increases with a higher fraction of convertible debt $\varphi$. The main intuition for this result is that a higher proportion of convertible debt increases the value of convertible debt at the expense of the existing shareholders. As a result, shareholders have incentives to default strategically earlier, implying a higher renegotiation threshold. Similarly, the conversion threshold also increases with the fraction of convertible debt. The reason for this effect is that convertible debt holders receive larger cash flows in the form of coupon payments and hence have fewer incentives to convert and forgo these payments.

$$
<\text { Insert Figures } 1 \text { and } 2 \text { about here }>
$$

Figure 2 displays comparative statics for the equity value and the equity beta for varying proportions of convertible debt $\varphi$. While the strategic default mechanism from the previous sections is still working in the presence of convertible debt, there is now an additional 
subtle interaction between shareholders' and convertible debt holders' optimal decisions. In particular, shareholders will default strategically if they believe that they are better off in renegotiation than if the firm continues its operations. Simultaneously, shareholders have to guess debt holders' optimal conversion strategy. This interaction between shareholders and convertible debt holders has the following implications for the effect of a higher fraction of convertible debt on the equity value and the equity beta. First, the equity value decreases with the proportion of convertible debt $\varphi$. The intuition for this effect is that convertible debt becomes more valuable as the proportion of convertible debt increases. This value increase of convertible debt comes at the expense of existing shareholders, implying a decrease in the equity value.

Second, an increasing fraction of convertible debt also represents a risk for shareholders' cash flows. Specifically, since payments to convertible debt holders increase with a higher $\varphi$, and debt holders delay the decision to convert, shareholders have to pay the higher coupon for a longer time. Moreover, shareholders face the risk of having to share their upside with convertible debt holders in case debt holders exercise their option to convert their claim into existing shareholders' equity. As a result, the equity beta and hence expected stock returns increase.

Prediction 3. Firms with a larger proportion of convertible debt have higher expected stock returns.

\section{Data and Descriptive Statistics}

This section describes the variables used in the analysis and presents descriptive statistics.

\section{A Secured and Convertible debt}

Secured and convertible debt are directly observable in the Compustat database. Hence, secured debt is the proportion of secured debt ( $\mathrm{dm})$ to total debt (dlc+dltt), and convertible 
debt is the proportion of convertible debt (cvd) to total debt.

\section{B Renegotiation frictions}

Renegotiation frictions are related to how easily debt renegotiations are carried out. Debt renegotiations are especially difficult when they involve many parties with diverse interests (Bolton and Scharfstein (1996); Hege and Mella-Barral (2005)). Bolton and Scharfstein (1996) argue, for instance, that dispersed public debt makes debt more difficult to renegotiate because of free-rider problems. Moreover, Bris, Welch, and Zhu (2006) find that the time that a Chapter 11 firm needs to confirm a reorganization plan is positively and significantly related to the number of creditors. Much like the dispersion of debt holders, the dispersion of shareholders also hinder renegotiation due to coordination problems. To capture this idea, I follow Davydenko and Strebulaev (2007) and use the number of institutional shareholders as a proxy for renegotiation frictions. More specifically, I use the normalized number of shareholders (Shareholders), defined as the logarithm of the number of different institutional shareholders divided by the logarithm of the market value of the firm's equity. ${ }^{7}$ In a robustness test, I use a Herfindahl index based on the proportion of ownership by each institutional investor as an alternative proxy for renegotiation frictions.

\section{Distance from the Renegotiation Threshold}

The model predicts that the effects of renegotiation frictions and secured debt on expected stock returns are stronger for firms close to the renegotiation threshold. Following the literature on bankruptcy prediction, I use Altman's (1968) Z-score to identify firms close to the renegotiation threshold. I calculate the Z-score for every firm-month observation. Next, I pool all observations and split the sample into quartiles based on the Z-score. Accordingly, the group of firms in the lowest Z-score quartile contains firms close to the renegotiation

\footnotetext{
${ }^{7}$ Favara, Schroth, and Valta (2012) use an international cross-section of firms and measure renegotiation frictions with bankruptcy code data at the country level.
} 
threshold, and the group of firms in the highest Z-score quartile contains firms far away from the renegotiation threshold. ${ }^{8}$ For robustness, and to provide further support for the results, I redo part of the analysis using two alternative measures of distress. The first measure is the probability of bankruptcy based on Zmijewski's (1984) multiple choice analysis. The second proxy is the default probability estimate constructed along the lines of Vassalou and Xing (2004) and Bharath and Shumway (2008). The results using these two alternative measures of distress generally support those I obtain using the Z-score.

\section{Data}

The sample is based on a panel of US firms over the period 1985 to 2012. Monthly stock market data come from the Center for Research in Security Prices (CRSP), annual financial statement data are from Standard \& Poor's Compustat, and institutional ownership data come from the Thomson Financial Ownership Database.

The sample includes all firms listed on the NYSE, AMEX, and NASDAQ with share codes 10 and 11 that are contained in the intersection of the CRSP monthly returns file and the Compustat industrial annual file. To ensure that the accounting variables are known before the returns they are used to explain, I match the accounting data for all fiscal year-ends in calendar year $t-1$ with the returns for July of year $t$ to June of year $t+1$ (Fama and French $(1992))$.

Size is CRSP market equity. Book equity is total assets (at) minus total liabilities $(\mathrm{dlc}+\mathrm{dltt})$. The book-to-market ratio is calculated by dividing book equity by Compustat market equity, which is Compustat stock price (prcc_f) times shares outstanding at

\footnotetext{
${ }^{8}$ Splitting the sample in four groups is admittedly arbitrary. This choice, however, tries to balance two offsetting concerns. On the one hand, I wish to capture firms with a Z-score low enough to identify firms that are close to the renegotiation threshold. On the other hand, making too many groups reduces the sample significantly and makes the portfolio construction unreliable. Choosing four groups strikes a balance between the two concerns. Although the results in the paper are presented with splits into four groups, in unreported tables I replicate most findings using more or less groups, and the results are qualitatively similar.
} 
fiscal year end (csho). Leverage is the ratio of book liabilities (total assets (at) minus book equity) to total market value of the firm. Momentum is the firm's past 12-month average return, skipping the most recent month.

I exclude financial firms (SIC codes between 6000 and 6999) and regulated firms (SIC codes above 9000). Moreover, a firm must have information on the book value of assets, the market value of equity, momentum, total debt (dlc+dltt), secured debt (dm), convertible

debt (cvd), and institutional ownership to be included in the sample. I also require that the sample contains at least 12 monthly observations per firm. Finally, I winsorize all variables at the one percent level in each tail to reduce the impact of outliers. Table 1 contains a summary and the definitions of the variables used in the empirical analysis.

$<$ Insert Table 1 about here $>$

\section{E Descriptive Statistics}

The final sample consists of 638,593 firm-month observations. Table 2 contains summary statistics for the main variables.

$<$ Insert Table 2 about here $>$

The mean return is positive with 0.96 percent and the median return is zero. This indicates a positively skewed distribution of stock returns, which is consistent with empirical findings. On average, firms have 90 institutional shareholders, with a median value of 38 . The average amount of secured debt held by firms is 36 percent, which is consistent with the number reported by Barclay and Smith (1995). On average, firms have 7 percent convertible debt outstanding, and 42 percent of firms' total debt is maturing within three years (shortterm debt). The average return over the past twelve months is 1.25 percent.

Since the type of debt financing plays an important role in this paper, Table 3 presents summary statistics by sub-samples based on whether or not firms have secured or convertible debt outstanding. 


\section{$<$ Insert Table 3 about here $>$}

Panel A contains descriptive statistics for firms without secured debt, and Panel B for firms with a positive amount of secured debt. Firms with no secured debt tend to be larger, have a higher Z-score, a lower default probability, and a lower book-to-market ratio.

Panel C and Panel D contain the same statistics for convertible debt. Firms without any convertible debt are smaller, and they have a higher Z-score and a lower default probability. The book-to-market ratio is slightly higher for firms without convertible debt outstanding.

\section{Results}

\section{A Fama and MacBeth Analysis}

To examine the relation between renegotiation frictions, debt structure, and stock returns, I perform a regression analysis using the Fama and MacBeth (1973) method. ${ }^{9}$ In each estimation, I control for firm characteristics that are known to affect stock returns. These characteristics include the size of a firm, the book-to-market ratio, and momentum returns (see Fama and French (1992); Carhart (1997)). Table 4 presents the estimation results.

$<$ Insert Table 4 about here $>$

Panel A of Table 4 presents the coefficient estimates for the full sample, absolute values of $t$-statistics in parentheses, and in brackets the changes in average monthly returns when the independent variable increases by one standard deviation. The model predicts that firms that face high renegotiation frictions have higher expected returns. The sign for the coefficient of renegotiation frictions should therefore be positive. Using the proxy Shareholders for renegotiation frictions, the estimate in column 1 of Table 4 supports this prediction. The coefficient of Shareholders has a value of 0.984 and is statistically significant at the one

\footnotetext{
${ }^{9} \mathrm{I}$ also estimate pooled regressions with monthly dummy variables and obtain very similar results.
} 
percent level. This finding corroborates the findings of Favara, Schroth, and Valta (2012) using a different sample and an alternative, firm-specific proxy for renegotiation frictions.

A similar result holds for secured debt. In column 2, the coefficient of Secured is positive and statistically significant. Adding Shareholders (column 3) does not change the coefficient nor the significance. This result supports the model's prediction that firms with a higher proportion of secured debt have higher returns. The results in Panel A of Table 4 also support the model's third prediction regarding convertible debt. ${ }^{10}$ The coefficient of Convertible is positive and statistically significant in columns 4 to 6 , indicating that firms with a higher proportion of convertible debt earn, on average, higher stock returns.

While the effects are statistically significant for all variables of interest, the economic impact is rather moderate for the full sample. An increase of one standard deviation in the variable Shareholders increases average stock returns by 17 basis points per month. Similarly, increasing the fraction of secured debt by one standard deviation leads, on average, to a 5-6 basis points increase in monthly stock returns. Finally, increasing the fraction of convertible debt by one standard deviation increases average stock returns by 14 basis points per month.

Regarding the control variables, the book-to-market ratio has a strong positive effect on stock returns, reflecting the value premium. Momentum is also positive and significant, while size is only weakly related to stock returns.

The model further predicts that the effects of renegotiation frictions and secured debt are stronger for firms close to the renegotiation threshold. To investigate this additional prediction, I reestimate the specification in columns 1, 2, and 3 for firms in the lowest and highest Z-score quartile, respectively. Panel B of Table 4 presents the results for both groups of firms.

\footnotetext{
${ }^{10}$ Since a large proportion of firms reports zero convertible debt, I include a dummy variable equal to one if a firm has convertible debt outstanding, and zero otherwise. I do this to isolate the effect of a higher proportion of convertible debt on stock returns (as predicted by the model).
} 
Columns 1 through 3 of Panel B present the results for firms close to the renegotiation threshold. Notably, the coefficient of Shareholders is positive with a value of 1.136 and is statistically significant. Compared to the full sample estimate, the coefficient is larger. In particular, the economic significance increases to 24 basis points per month. Similarly, the coefficient of Secured is also positive and significant. Notably, the economic significance doubles to 11 basis points per month.

Columns 4 through 6 show results for firms farther away from the renegotiation threshold. The coefficient of Shareholders is much smaller and barely statistically significant. The economic significance also decreases to 10 basis points per month. The coefficient of Secured is also smaller and becomes statistically insignificant. These results support the prediction that the effects of renegotiation frictions and secured debt on stock returns are stronger for firms close to the renegotiation threshold. Taken together, the analysis in this section provides evidence that renegotiation frictions and the debt structure are systematically related to stock returns.

\section{B Factor Model Regressions}

In this section, I investigate the relation between renegotiation frictions, debt structure, and stock returns by computing abnormal returns (alphas) from factor models. These models are the Fama and French (1993) thee-factor model including the market return, the size, and book-to-market factor, the four-factor model including the Carhart (1997) momentum factor, and the five-factor model including the Pastor and Stambaugh (2003) liquidity factor. ${ }^{11}$

To compute these abnormal returns, I sort stocks, at the beginning of each calendar month, into five quantiles based on either the proxy for renegotiation frictions, the proportion of secured debt, or the proportion of convertible debt. For each quantile, I then compute the alpha as the intercept on a regression of monthly excess returns (over the risk-free rate) on explanatory variables that include the monthly returns from the Fama and French (1993)

\footnotetext{
${ }^{11}$ I thank Kenneth French for providing the data on factor-mimicking portfolios in his data library.
} 
mimicking portfolios, the Carhart (1997) momentum factor, and the Pastor and Stambaugh (2003) liquidity factor. I compute these alphas using all the individual stocks by quantile. Alternatively, I collapse the data at the monthly frequency and compute equal-weighted or value-weighted returns for each quantile. These equal- or value-weighted returns are then in turn regressed on the factor mimicking portfolios. I also compute the difference in alphas between the highest and lowest quantile as a zero-cost long-short (L/S) portfolio.

Table 5 reports the results for the portfolio analysis. Panel A contains the results for Shareholders as a proxy renegotiation frictions for firms in the lowest and highest Z-score quartile, respectively. The model predicts that firms that face high renegotiation frictions have higher expected returns. The average return should thus increase from quantile 1 (lowest renegotiation frictions) to quantile 5 (highest renegotiation frictions). Moreover, this effect should be stronger for firms close to the renegotiation threshold. The results in Panel A of Table 5 support this prediction. In particular, in the upper part of Panel A, which contains firms in the lowest Z-score quartile, the monthly excess return (column 1) increases from $0.31 \%$ in the first quantile to $1.13 \%$ in the fifth quantile. A simple strategy that holds the firms in the highest quantile and sells short the firms in the lowest quantile (L/S) yields a return of 82 basis points per months $(t=7.64)$ or roughly 9.8 percentage points per year. This result remains unaffected by the inclusion of well known factors. In all columns, the strategy of going long the fifth quantile and selling short the firms in the lowest quantile yields positive and significant alphas between 59 (three-factor alpha) and 74 basis points (equal-weighted portfolio five-factor alpha) per month.

The lower part of Panel A reports excess returns and alphas from the same models but for firms in the highest Z-score quartile. The results show that a portfolio that holds the firms in the highest quantile and sells short the firms in the lowest quantile still yields a positive abnormal return. However, the numbers are economically much smaller compared to those where firms are close to the renegotiation threshold. For instance, the L/S fivefactor alpha portfolio yields an abnormal return of 71 basis points per month for distressed 
firms, while the same strategy only yields 35 basis points per month for firms farther away from the renegotiation threshold. Moreover, for the equal and value-weighted portfolio, the L/S strategy does not yield statistically significant alphas for firms farther away from the renegotiation threshold.

$<$ Insert Table 5 about here $>$

A similar result holds for secured debt. In the upper part of Panel B, the alpha of the fifth quantile is positive and statistically significant in four out of six cases. Similarly, the strategy of holding the firms in the fifth quantile and shorting the firms in the lowest quantile

yields abnormal returns between 20 and 38 basis per month. By contrast, the alpha of the fifth quantile for firms with a high Z-score is often negative and/or statistically insignificant (lower part of Panel B).

Panel C shows the results for convertible debt. Since the model predicts an unconditional relation between the proportion of convertible debt and expected stock returns, Panel C presents the results for the full sample. In all specifications, the alpha is larger for the fifth quantile compared to the first quantile. Importantly, the alpha of firms in the fifth quantile is positive and significant in all cases. Moreover, the strategy of going long the firms in the fifth quantile and short the firms in the first quantile yields abnormal returns between 32 and 68 basis points per month. These numbers are statistically significant and economically large.

\section{Discussion}

So far, the analysis has shown that the variables Shareholders, Secured, and Convertible affect stock returns even after taking into account other factors (size, book-to-market ratio, and momentum). The reason put forth in this paper why these variables are relevant in explaining stock returns is that they capture a specific dimension of a firm's exposure to risk factors. From the model we know that this dimension relates to the strategic behavior of shareholders 
in default, and their possibilities to extract rents from creditors. This dimension becomes most relevant for firms close to the default threshold, and it seems that this effect is not correctly measured by the other variables accounting for the cross-section of expected stock returns. Thus, the effect explored in this paper does not necessarily identify a new priced factor, but rather points to an important economic mechanism that relates renegotiation frictions, debt structure, and strategic default to stock returns.

\section{Robustness and Further Evidence}

This section contains robustness checks to further support the main results.

\section{A Instrumental Variables Estimation}

A potential concern with the inference so far is that the proportion of secured and convertible debt could be endogenously determined. In this section, I address this issue by using an instrumental variable regression. I use instruments for secured and convertible debt that are likely to meet the relevance and exclusion restrictions. ${ }^{12}$ The relevance restriction requires that the instrument has a clear effect on the endogenous variables (secured or convertible debt). The exclusion restriction requires that the instrument should be uncorrelated with any other determinants of the dependent variable in the second stage (stock returns). In other words, and in the context of this paper, the instrument has no effect on stock returns other than indirectly through the first stage channel, i.e. through its effect on secured or convertible debt.

My first instrument for secured and convertible debt is a dummy variable equal to one for utility industries (four-digit SIC between 4900 and 4999), and zero otherwise. Recent research suggests that collateral is a first-order determinant of capital structure (see, e.g., Rampini and Viswanathan (2013)). Since utility firms typically have valuable tangible assets

\footnotetext{
${ }^{12}$ See, for instance, Angrist and Pischke (2009) for a discussion of these restrictions.
} 
that can serve as collateral and increase the firm's debt capacity, the utility industry dummy is likely to be significantly related to debt capacity and hence to the firm's ability to raise secured or convertible debt. Furthermore, I do not expect the utility industry dummy to be systematically related to stock returns other than through its effect on debt capacity and capital structure. As a result, the exclusion restriction is likely to be satisfied.

The second instrument for secured debt is the one year lagged secured debt. Indeed, the lag of secured debt should capture systematic differences in the level of secured debt and is likely to be positively related to the level of secured debt in the next year. At the same time, there is no reason to believe that the lagged accounting value of secured debt has a systematic effect on contemporaneous stock returns other than through its effect on the contemporaneous level of secured debt.

For convertible debt, I also use the utility industry dummy and the one year lagged proportion of convertible debt as instruments. Because the convertible debt regression includes the additional dummy variable dconv, which equals one if the firm has convertible debt outstanding, and zero otherwise, I add a third instrumental variable to have an overidentified system. Specifically, I use as an instrument a dummy variable equal to one if the firm has a credit rating, and zero otherwise. Indeed, research suggests that the presence of a credit rating is positively and significantly related to financial leverage (Faulkender and Petersen (2006)). Furthermore, it seems implausible that the presence of a credit rating would systematically impact stock returns other than through its impact on the firm's level of debt.

Table 6 reports the first and second stage estimation results of these instrumental variable regressions for secured and convertible debt. The results confirm the findings of the previous sections. The coefficient of secured debt is significantly positive for firms close to the renegotiation threshold (column 2). The coefficient is also significantly larger compared to the Fama and MacBeth estimates (the coefficient increases from 0.002 to 0.005). Furthermore, the results from the first stage regression suggest that the instruments are significantly 
related to the proportion of secured debt. Finally, the $p$-value from a test of overidentifying restrictions shows that the joint null hypothesis that the instruments are valid cannot be rejected. Noteworthy, and as expected, the coefficient of Secured is not significantly different from zero for firms in the highest Z-score quartile (column 4).

$<$ Insert Table 6 about here $>$

The coefficient estimates for convertible debt are also positive and statistically significant (column 7), supporting the results of the Fama and MacBeth (1973) estimations and the portfolio analysis. Also, the $p$-value of the test of overidentifying restrictions is above the critical level to reject instrument validity. Overall, the results using instrumental variable regressions provide further support for the model's predictions and the main results.

\section{B Alternative Proxy for Renegotiation Frictions}

This section explores the relation between an alternative proxy for renegotiation frictions and stock returns. Specifically, I compute a Herfindahl index (HHI) based on the equity ownership by each institutional investor. This measure should take into account the voting power differences among institutional shareholders. It has a high value when institutional ownership is concentrated, and a low value when there are many institutional investors with relatively small ownership stakes. Admittedly, debt renegotiation will be easier with a more concentrated ownership structure, as coordination among relatively few large shareholders is easier than among many small shareholders (see also Davydenko and Strebulaev (2007)). Hence, low values of the Herfindahl index should be related to high renegotiation frictions, and vice versa.

To construct the proxy, I extract the proportion of shares held by every institutional investor in each quarter from the Thomson Financial Ownership database, and then compute the HHI for every firm in my sample. Since these voting power differences are more important

for firms with a higher fraction of institutional ownership, the tests in this section only 
consider firms with at least $15 \%$ of shares held by institutional investors. The results are robust to variations in this cutoff level.

$<$ Insert Table 7 about here $>$

I sort stocks into five quantiles based on this HHI, and then estimate abnormal returns from factor models. Table 7 presents the abnormal returns from these estimations for firms in the lowest and highest Z-score quartile, respectively. The results largely confirm the results from the previous sections. Notably, the alphas are significantly higher in the lowest quantile (high renegotiation frictions) compared to the highest quantile (low renegotiation frictions). For instance, in column 1, the alpha from a four-factor model is 52 basis points per month and statistically significant in the lowest quantile, while the alpha is 10 basis points (insignificant) in the highest quantile. As a result, the strategy of going long the stocks in the lowest quantile and selling short the firms in the highest quantile yields a positive and significant alpha of 42 basis points per month. This result becomes slightly weaker for the equal and value-weighted portfolio abnormal returns. The return difference between highest and lowest quantile drops to around 30 basis points and looses statistical significance. However, the alphas in the lowest HHI quantile are positive and significant across all factor models. By contrast, the results are much weaker for firms farther away from the renegotiation threshold. In particular, the return difference of a long-short portfolio is economically smaller and statistically not significant.

\section{Renegotiation Frictions Around Chapter 11 filings}

To provide further supporting evidence of the effect of renegotiation frictions on distressed stock returns, I collect data on actual Chapter 11 filings from the LoPucki Bankruptcy Research Database. ${ }^{13}$ The LoPucki Database provides information on each bankrupt firm, such as which chapter was filed, whether or not the filing was voluntary, the length of the

\footnotetext{
${ }^{13}$ This database can be obtained through http://lopucki.law.ucla.edu/request_download.htm.
} 
procedure, etc. I match this data with my sample of firms and identify 417 Chapter 11 filings. For each firm, I keep observations from a maximum of five years before and three years after Chapter 11 filing, and sort firms into two groups based on the median time spent in bankruptcy. Next, I split the sample at the median based on the main proxy for renegotiation frictions, Shareholders. I then estimate five-factor models and investigate the return premium for firms with high relative to low renegotiation frictions. ${ }^{14}$ Table 8 reports the results.

\section{$<$ Insert Table 8 about here $>$}

The first pattern to note from Table 8 is that abnormal returns are negative for all groups. This finding is consistent with the fact that firms around bankruptcy filings experience important value losses. Furthermore, it turns out that the abnormal returns on the L/S portfolio are positive and economically large, ranging from 15 basis points to 3.74 percentage points. This result suggests that firms with higher renegotiation frictions (Shareholders is above the median) earn reliably higher returns around Chapter 11 filings. Thus, it seems that shareholders of firms that expect renegotiations to be more difficult demand higher distress premia. Interestingly, the length of the bankruptcy procedure does not seem to have an important effect on this result. Overall, the tests in this section further support the view that renegotiation frictions are relevant determinants of distress premia in the cross-section of stocks.

\footnotetext{
${ }^{14}$ Balwin and Mason (1983) investigate the dynamics of the equity beta around the bankruptcy of one particular firm and find evidence consistent with deviations from the absolute priority rule. Similary, Hackbarth, Haselmann, and Schoerherr (2013) analyze the distress return premium for firms with and without absolute priority deviations deviations and find evidence consistent with the view that shareholders' recovery and bargaining in default are important factors in explaining distress return premia.
} 


\section{Alternative Measures of Distress}

In an additional robustness test, I use two alternative measures for firms' distance to the renegotiation threshold. The first proxy is based on Zmijewski's (1984) probit model for predicting bankruptcy. ${ }^{15}$ I construct two groups of firms based on the median Zmijewski score. Firms with a score above the median are considered to be closer to the renegotiation threshold, and firms with a score below the median are considered to be farther away from the renegotiation threshold. Panel A of Table 9 reports abnormal returns from five factor models for quantiles based on Shareholders and Secured.

$$
<\text { Insert Table } 9 \text { about here }>
$$

The results in Panel A of Table 9 show that, for Shareholders, abnormal returns are economically larger for firms closer to the renegotiation threshold. For instance, while the value-weighed L/S portfolio yields an abnormal return of 40 basis points for firms with a Zmijewski score above the median, the abnormal return of the same portfolio for firms with a score below the median is only 28 basis points. The results for secured debt are slightly weaker, but still support the idea that the effect is larger for firms closer to the renegotiation threshold.

The second additional measure is a default probability estimate, constructed along the lines of Bharath and Shumway (2008). As before, I make two groups of firms based on the below- and above-median probability of default. Panel B of Table 9 presents the results. The results are broadly consistent with the results in Panel A, again with slightly weaker results for secured debt. Taken together, these results suggest that the main findings of this paper are not very sensitive to a specific measure of financial distress.

\footnotetext{
${ }^{15}$ The probability of default based on the Zmijewski model is

$N\left(-4.3-4.5\left(\frac{\text { NetIncome }}{\text { TotalAssets }}\right)+5.7\left(\frac{\text { TotalLiabilities }}{\text { TotalAssets }}\right)-0.004\left(\frac{\text { CurrentAssets }}{\text { CurrentLiabilities }}\right)\right)$, where $\mathrm{N}$ is the standard cu-
} mulative normal distribution function. 


\section{E Short- and Long-Term Debt}

So far, the evidence in this paper suggests that the proportions of secured and convertible debt are positively related to average stock returns. As such, the paper's focus was on specific types of debt. However, another natural dimension of debt structure to investigate is the split between short- and long-term debt. Indeed, theoretical research (see, e.g., Gertner and Scharfstein (1991), or Berglöf and von Thadden (1994)) suggests that the presence of short-term debt makes debt renegotiation more difficult, because short-term lenders have little incentives to forgive debt when the concessions accrue to subordinated long-term debt holders. Thus, recent empirical research uses the firm's proportion of short-term debt as a proxy for renegotiation frictions and relates it to the pricing of debt and equity (see Davydenko and Strebulaev (2007) and Zhang (2012)).

To investigate the relation between short-term debt and stock returns in the context of this paper's research design, I follow these papers and compute each firm's short-term debt as debt maturing within three years divided by total debt. Next, each calendar month, for firms with a low and high Z-score respectively, I sort stocks into five quantiles based on the firm's short-term debt. I then estimate factor models to compute abnormal returns. Table 10 shows the results.

$<$ Insert Table 10 about here $>$

Interestingly, for firms located in the lowest Z-score quartile, the abnormal returns for firms with the highest proportion of short-term debt (quantile 5) are significantly higher compared to the abnormal returns of firms with the lowest proportion of short-term debt (quantile 1). For instance, for the value-weighted portfolio, the abnormal return is -29 basis points per months for the lowest short-term debt quantile, and +29 basis points per months for the highest short-term debt quantile. As a result, the L/S strategy yields an economically large abnormal return of 58 basis per month. For firms in the highest Z-score quartile, the differences in abnormal returns between the lowest and highest short-term debt quantile are 
much smaller in magnitude and not systematically different from zero. Hence, the results in this section somewhat mirror the results using Shareholders or the HHI as a proxy for renegotiation frictions. Therefore, and as suggested by the literature, the proportion of short-term debt could be used as an additional proxy for frictions in the debt renegotiation process.

\section{Conclusion}

This paper analyzes whether renegotiation frictions and the firm's debt structure affect expected stock returns. In the model, shareholders can act strategically to induce default and recover a substantial fraction of firm value in renegotiation. The model generates predictions on the relation between renegotiation frictions, secured and convertible debt, and stock returns. In particular, the model predicts that firms that face more renegotiation frictions, and that have a greater fraction of secured debt or convertible debt, have higher expected stock returns.

Using a large sample of publicly traded US firms between 1985 and 2012, I find strong support for the model's predictions. Moreover, the main results are robust to a possible endogeneity bias and to alternative measures of renegotiation frictions and distress. Overall, these new results highlight an important link between debt structure and stock returns, and suggest that the allocation of property rights implicit in debt covenants is an important determinant of stock returns.

One dimension of firms' debt structure not explored in this paper is the firms' proportion

of public to total debt. Hence, a potential avenue for further research is to explore how the proportion of public to total debt relates to stock returns, either through the channel proposed in this paper, or through another mechanism. I leave this question for future research. 


\section{Appendix: Derivation}

\section{Straight debt.}

Given the dynamics of the cash flow shock, $X$, in equation 1 , the after-tax cash flow to shareholders is $\pi\left(X_{t}\right)=\left(X_{t}-c\right)(1-\tau)$. In equilibrium, this after-tax cash flow plus the expected change in the value of equity, $\pi\left(X_{t}\right)+d E$, must be equal to the risk free return. Applying Itô's lemma, the value of equity, $E(X)$, satisfies the following ordinary differential equation (ODE)

$$
\frac{1}{2} \sigma^{2} X^{2} E_{X X}+\mu^{Q} X E_{X}+(1-\tau)(X-c)=r E,
$$

where $E_{X}$ and $E_{X X}$ are the first and second derivatives of the equity value with respect to the cash flow $X$. The ODE is solved subject to the value-matching, smooth-pasting, and no-bubbles condition:

$$
\begin{gathered}
\lim _{X \downarrow X_{B}} E(X)=(1-q) \eta \alpha \frac{X_{B}}{r-\mu^{Q}}(1-\tau), \\
\lim _{X \downarrow X_{B}} E_{X}(X)=(1-q) \eta \alpha \frac{1}{r-\mu^{Q}}(1-\tau), \\
\lim _{X \uparrow \infty} E(X) / X \leq \infty .
\end{gathered}
$$

The general solution to the ODE is

$$
E(X)=A X^{\lambda_{1}}+B X^{\lambda}+(1-\tau)\left(\frac{X}{r-\mu^{Q}}-\frac{c}{r}\right),
$$

where $\lambda_{1}$ and $\lambda$ are given by

$$
\begin{aligned}
& \lambda_{1}=\left(\frac{1}{2}-\frac{\mu^{Q}}{\sigma^{2}}\right)+\sqrt{\left(\frac{1}{2}-\frac{\mu^{Q}}{\sigma^{2}}\right)^{2}+\frac{2 r}{\sigma^{2}}}>0, \\
& \lambda=\left(\frac{1}{2}-\frac{\mu^{Q}}{\sigma^{2}}\right)-\sqrt{\left(\frac{1}{2}-\frac{\mu^{Q}}{\sigma^{2}}\right)^{2}+\frac{2 r}{\sigma^{2}}}<0 .
\end{aligned}
$$

The last boundary condition implies that $A=0$. Using the value-matching condition in combination with the general solution yields

$$
B=\left[(1-q) \eta \alpha \frac{X_{B}}{r-\mu}(1-\tau)-(1-\tau)\left(\frac{X_{B}}{r-\mu^{Q}}-\frac{c}{r}\right)\right]\left(\frac{1}{X_{B}}\right)^{\lambda} .
$$

Replacing B into the general solution, solving for the endogenous renegotiation threshold, $X_{B}$, and simplifying yields the expression for equity value, $E(X)$, in Proposition 1. 
Using the same techniques, the value of debt is given by

$$
D(X)=\frac{c}{r}\left[1-\left(\frac{X}{X_{B}}\right)^{\lambda}\right]+\left[(1-(1-q) \eta \alpha-\alpha q) \frac{X_{B}}{r-\mu^{Q}}(1-\tau)\right]\left(\frac{X}{X_{B}}\right)^{\lambda}
$$

Applying Itô's Lemma to the value of equity and dividing by $E_{t}$ yields

$$
\frac{d E_{t}}{E_{t}}=\frac{1}{E_{t}}\left(\mu^{Q} X_{t} \frac{\partial E}{\partial X}+\frac{1}{2} \sigma_{X}^{2} X_{t}^{2} E_{X X}\right) d t+\sigma \frac{\partial E}{\partial X} \frac{X_{t}}{E_{t}} d B_{t},
$$

where the term $\frac{\partial E}{\partial X} \frac{X_{t}}{E_{t}}$ corresponds to the equity beta, $\beta_{E}$, in equation 3 . Next, taking the derivative of the equity beta, $\beta_{E}$, with respect to $q$, yields

$$
\frac{\partial \beta_{E}}{\partial q}=\frac{\partial \beta_{E}}{\partial E} \frac{\partial E}{\partial q}=\underbrace{-\frac{\Omega(1-\tau)}{E^{2}}}_{-} \underbrace{\frac{\partial E}{\partial q}}_{-}>0
$$

where $\beta_{E}$ can be rewritten as

$$
\beta_{E}=\frac{\Omega(1-\tau)}{E}+\lambda
$$

and

$$
\Omega=X /\left(r-\mu^{Q}\right)-\lambda\left(X /\left(r-\mu^{Q}\right)-c / r\right)>0 .
$$

Because the expected return, $E R$, is a linear function of the equity beta, it follows that $\partial E R / \partial q>0$.

\section{Secured Debt.}

The value of equity satisfies the same ODE as in the straight debt case. The valuematching, smooth-pasting, and no-bubbles conditions are given by

$$
\begin{aligned}
\lim _{X \downarrow X_{B}} E^{S}(X)= & (1-q) \eta \alpha(1-\pi) \frac{X_{B}}{r-\mu^{Q}}(1-\tau), \\
\lim _{X \downarrow X_{B}} E_{X}^{S}(X)= & (1-q) \eta \alpha(1-\pi) \frac{1}{r-\mu^{Q}}(1-\tau) . \\
& \lim _{X \uparrow \infty} E^{S}(X) / X \leq \infty .
\end{aligned}
$$

Using the same form of general solution in combination with the value-matching and smoothpasting conditions, algebraic derivations yield the expressions for the equity value, $E^{S}$, and the renegotiation threshold, $X_{S}$, in Proposition 2. The debt value is given by 
$D^{S}(X)=\frac{c}{r}\left[1-\left(\frac{X}{X_{S}}\right)^{\lambda}\right]+\left[(1-(1-q) \eta \alpha(1-\pi)-\alpha q(1-\pi)) \frac{X_{S}}{r-\mu^{Q}}(1-\tau)\right]\left(\frac{X}{X_{S}}\right)^{\lambda}$.

\section{Convertible Debt.}

The value of equity satisfies the same differential equation as in the straight and secured debt case. The lower and upper boundary conditions to price equity in the presence of convertible debt are as follows:

$$
\begin{gathered}
\lim _{X \downarrow X_{B}} E(X)=(1-q) \eta \alpha \frac{X_{D}}{r-\mu^{Q}}(1-\tau), \\
\lim _{X \downarrow X_{B}} E_{X}(X)=(1-q) \eta \alpha \frac{1}{r-\mu^{Q}}(1-\tau), \\
\lim _{X \uparrow X_{C}} E(V)=(1-\gamma) E^{\prime}\left(X_{C}\right) .
\end{gathered}
$$

Using the first and third boundary condition and same form of general solution as in the straight debt case, algebraic manipulation yields the value of equity in Proposition 3.

The boundary conditions for pricing convertible debt are:

$$
\begin{gathered}
\lim _{X \downarrow X_{B}} D^{C}(X)=[\varphi(1-q)(1-\eta \alpha)+\varphi q(1-\alpha)] \frac{X_{D}}{r-\mu^{Q}}(1-\tau), \\
\lim _{X \uparrow X_{C}} D^{C}(X)=\gamma E^{\prime}\left(X_{C}\right), \\
\lim _{X \uparrow X_{C}} D_{X}^{C}(X)=\gamma \frac{\partial E^{\prime}\left(X_{C}\right)}{\partial X_{C}} .
\end{gathered}
$$

Similarly, using conditions one and three and the general solution to the differential equation yields the following value of convertible debt, $D^{C}(X)$,

$$
\begin{aligned}
D^{C}(X)= & \frac{c c}{r}+A R\left((1-(1-q) \alpha \eta-q \alpha) \varphi \frac{X_{D}}{r-\mu^{Q}}(1-\tau)-\frac{c c}{r}\right) \\
& +A C\left(\gamma E^{\prime}\left(X_{C}\right)-\frac{c c}{r}\right)
\end{aligned}
$$

where $A R$ and $A C$ are given in Proposition 3. 

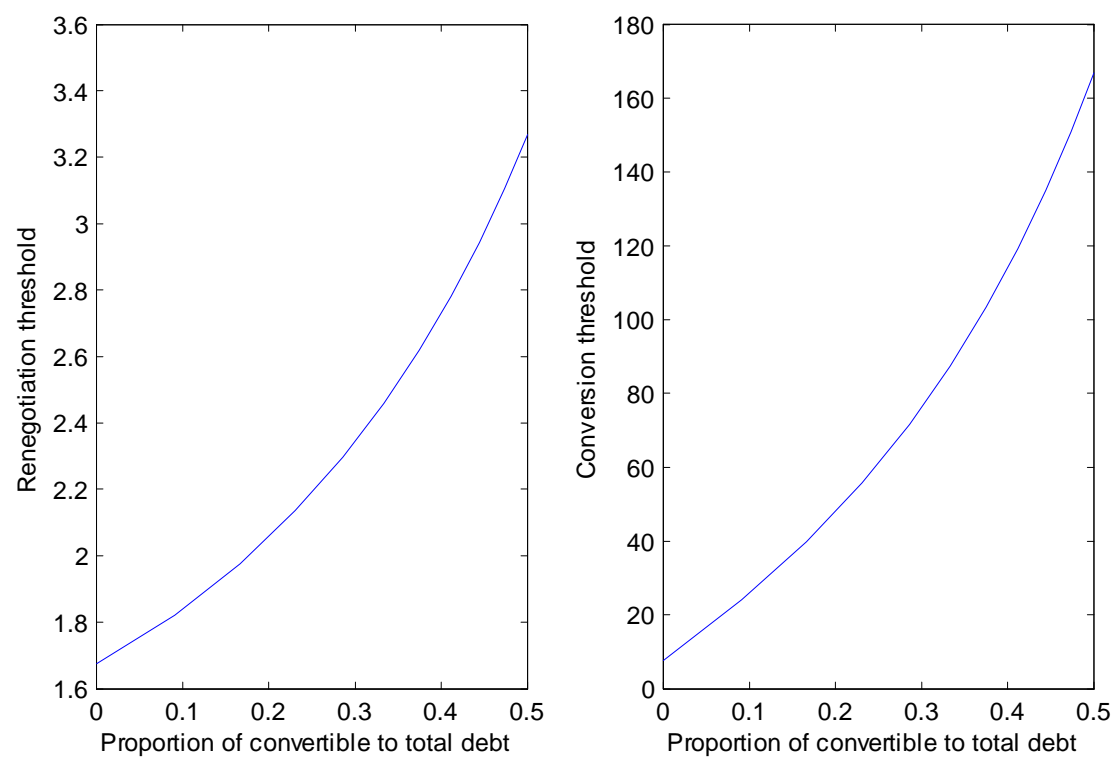

Figure 1: This figure shows the renegotiation and conversion thresholds for various proportions of convertible debt to total debt $\varphi$. The model's parameters are set to $\tau=0.35, r=$ $0.06, \mu^{Q}=0.02, \xi=0.02, \sigma=0.3, X=10, \gamma=0.5, q=0.5, \eta=$ $0.5, \alpha=0.05$.
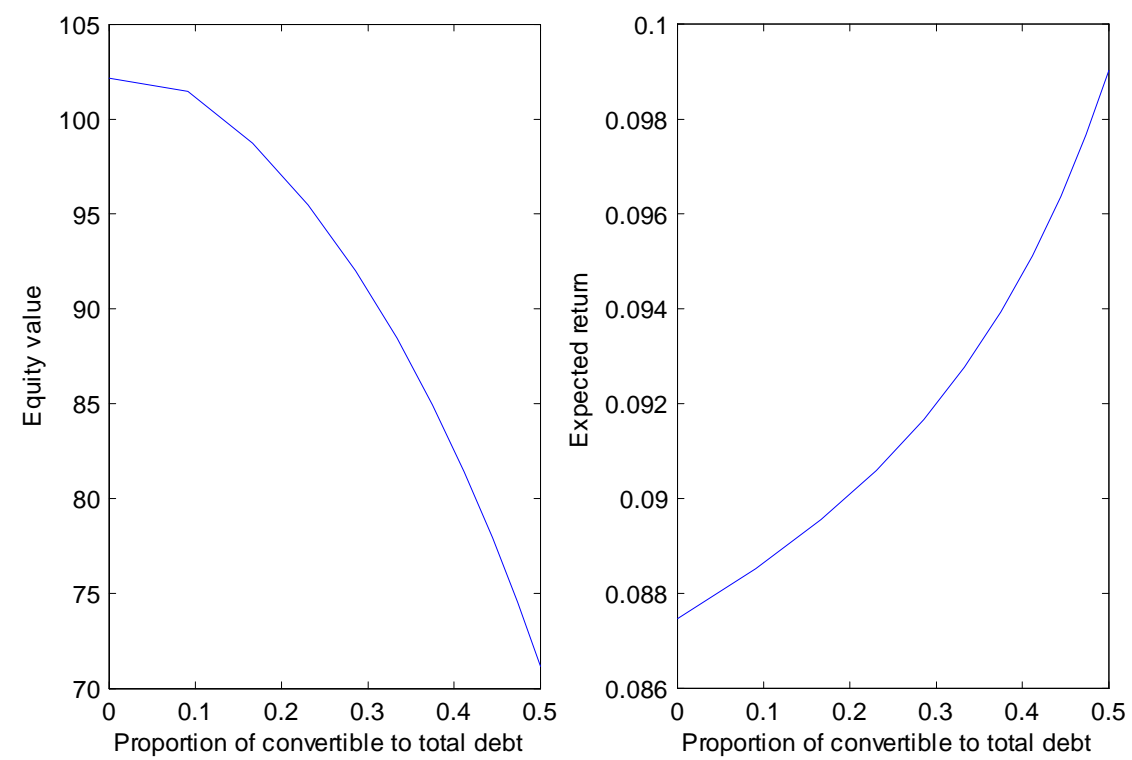

Figure 2: This figure shows the value of equity and the expected stock return for various proportions of convertible debt to total debt $\varphi$. The model's parameters are set to $\tau=0.35, r=$ $0.06, \mu^{Q}=0.02, \xi=0.02, \sigma=0.3, X=10, \gamma=0.5, q=0.5, \eta=$ $0.5, \alpha=0.05$. 


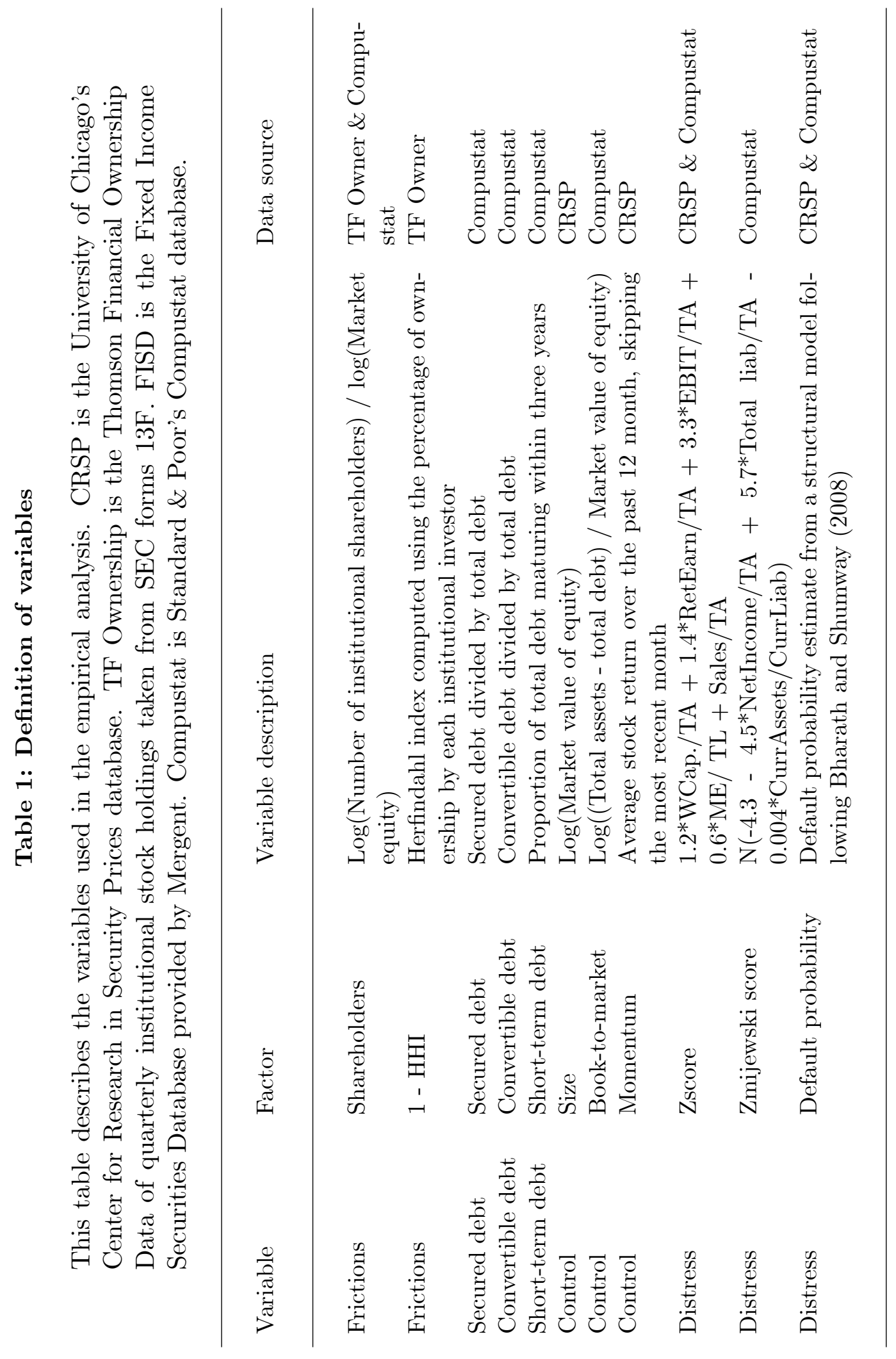




\section{Table 2: Descriptive statistics}

This table reports summary statistics for the variables in the sample. The sample period is 1985 to 2012. Return is the monthly stock return, Shareholders is the normalized number of institutional shareholders, HHI is the HerfindahlHirschman index measuring the ownership concentration of institutional investors, Short-term debt is the proportion of total debt maturing within three years, Secured debt is the proportion of secured to total debt, Convertible debt is the proportion of convertible to total debt, Size is the logarithm of the market value of equity, Book-to-market is the book-to-market ratio, Momentum is the average stock return over the past 12 month, Zscore is Altman's (1968) Zscore, Zmijewski score is the Default probability based on Zmijewski (1984), and default probability is a default probability estimate from a structural model. Please refer to Table 1 for a definition of the variables.

\begin{tabular}{lrrrrrr}
\hline & Mean & $25 \%$ & Median & $75 \%$ & Std. Dev. & $\mathrm{N}$ \\
& & & & & & \\
\hline & & & & & & \\
Return (\%) & 0.96 & -7.35 & 0.00 & 7.97 & 15.70 & 638,593 \\
Nb. of shareholders & 90.05 & 12.00 & 38.00 & 113.00 & 140.40 & 638,593 \\
Shareholders & 0.67 & 0.62 & 0.68 & 0.75 & 0.18 & 638,593 \\
HHI & 0.02 & 0.00 & 0.01 & 0.03 & 0.02 & 638,593 \\
Secured debt & 0.36 & 0.00 & 0.21 & 0.72 & 0.38 & 638,593 \\
Convertible debt & 0.07 & 0.00 & 0.00 & 0.00 & 0.22 & 638,593 \\
Short-term debt & 0.42 & 0.10 & 0.32 & 0.74 & 0.35 & 537,589 \\
Size & 5.24 & 3.72 & 5.14 & 6.67 & 2.05 & 638,593 \\
Book-to-market & 1.19 & 0.49 & 0.84 & 1.41 & 1.33 & 638,593 \\
Momentum (\%) & 1.25 & -1.43 & 1.05 & 3.58 & 4.90 & 638,593 \\
Zscore & 4.22 & 2.02 & 3.27 & 5.01 & 5.86 & 620,827 \\
Zmijewski score & 0.20 & 0.01 & 0.07 & 0.29 & 0.28 & 621,349 \\
Default probability & 0.24 & 0.00 & 0.08 & 0.44 & 0.29 & 638,593 \\
& & & & & & \\
\hline
\end{tabular}




\section{Table 3: Descriptive statistics by subsamples}

This table reports summary statistics for firms with and without secured and convertible debt, respectively. The sample period is 1985 to 2012. Return is the monthly stock return, Total assets is total book assets, Book-to-market is the book-to-market ratio, Zscore is Altman's (1968) Zscore, and Default probability is a default probability estimate from a structural model. Please refer to Table 1 for a definition of the variables.

Panel A: Firms with no secured debt

\begin{tabular}{lrrrrrr} 
& Mean & $25 \%$ & Median & $75 \%$ & Std. Dev. & N \\
\hline & & & & & & \\
Return (\%) & 0.96 & -6.49 & 0.25 & 7.41 & 14.46 & 165,682 \\
Total assets & $1,924.78$ & 82.22 & 371.71 & $1,436.18$ & $4,659.64$ & 165,682 \\
Book-to-market & 1.00 & 0.44 & 0.74 & 1.19 & 1.09 & 165,682 \\
Zscore & 4.50 & 2.41 & 3.70 & 5.48 & 5.90 & 161,589 \\
Default probability & 0.20 & 0.00 & 0.02 & 0.41 & 0.26 & 165,682 \\
\hline
\end{tabular}

Panel B: Firms with secured debt

\begin{tabular}{lrrrrrr} 
Return (\%) & 0.96 & -7.69 & 0.00 & 8.21 & 16.12 & 472,911 \\
Total assets & $1,221.27$ & 45.28 & 155.37 & 650.54 & $3,792.26$ & 472,911 \\
Book-to-market & 1.25 & 0.50 & 0.88 & 1.49 & 1.39 & 472,911 \\
Zscore & 4.12 & 1.89 & 3.11 & 4.82 & 5.84 & 459,238 \\
Default probability & 0.25 & 0.00 & 0.10 & 0.46 & 0.30 & 472,911 \\
\hline
\end{tabular}

Panel C: Firms with no convertible debt

\begin{tabular}{lrrrrrr} 
Return (\%) & 1.00 & -7.27 & 0.00 & 7.94 & 15.63 & 542,784 \\
Total assets & $1,289.35$ & 47.22 & 166.11 & 717.44 & $3,879.60$ & 542,784 \\
Book-to-market & 1.19 & 0.49 & 0.85 & 1.41 & 1.33 & 542,784 \\
Zscore & 4.52 & 2.16 & 3.44 & 5.26 & 6.02 & 528,142 \\
Default probability & 0.22 & 0.00 & 0.05 & 0.42 & 0.28 & 542,784 \\
\hline
\end{tabular}

Panel D: Firms with convertible debt

\begin{tabular}{lrrrrrr} 
Return (\%) & 0.74 & -7.82 & 0.00 & 8.15 & 16.08 & 95,809 \\
Total assets & $2,052.18$ & 96.18 & 428.97 & $1,562.78$ & $4,837.55$ & 95,809 \\
Book-to-market & 1.15 & 0.45 & 0.82 & 1.39 & 1.29 & 95,809 \\
Zscore & 2.53 & 1.43 & 2.45 & 3.63 & 4.43 & 92,685 \\
Default probability & 0.33 & 0.00 & 0.32 & 0.55 & 0.31 & 95,809 \\
\hline
\end{tabular}




\section{Table 4: Fama and MacBeth analysis}

This table presents estimates from Fama and MacBeth (1973) regressions. The dependent variable is the monthly stock return. Shareholders is the normalized number of institutional shareholders, Secured is the proportion of secured to total debt, Convertible is the proportion of convertible to total debt, and dconv is a dummy equal to one if the firm has convertible debt outstanding, and zero otherwise. The sample period is 1985 to 2012. Please refer to Table 1 for a definition of the variables. Panel A presents results for the full sample. In Panel B, columns 1 through 3 show results for firms in the lowest Z-score quartile, and columns 4 through 6 show results for firms in the highest Z-score quartile. Newey and West (1987) $t$-statistics adjusted for autocorrelation for up to six lags are reported in parentheses below the coefficient estimates. The numbers in brackets are the changes in average monthly returns when the independent variable increases by one standard deviation. Coefficients marked $* * *, * *$, and $*$ are significant at the $1 \%, 5 \%$, and $10 \%$ significance level, respectively.

\section{Panel A: Full sample}

$(1)$

$(2)$

\begin{tabular}{|c|c|c|c|c|c|c|}
\hline Shareholders & $\begin{array}{l}0.984^{\text {*** }} \\
(0.298) \\
{[0.17]}\end{array}$ & & $\begin{array}{l}0.981^{* * *} \\
(0.298) \\
{[0.17]}\end{array}$ & & $\begin{array}{l}0.978^{* * *} \\
(0.294) \\
{[0.17]}\end{array}$ & $\begin{array}{l}0.971^{* * *} \\
(0.294) \\
{[0.17]}\end{array}$ \\
\hline Secured & & $\begin{array}{l}0.001^{* *} \\
(0.001) \\
{[0.05]}\end{array}$ & $\begin{array}{l}0.001^{* *} \\
(0.001) \\
{[0.05]}\end{array}$ & & & $\begin{array}{l}0.002^{* *} \\
(0.001) \\
{[0.06]}\end{array}$ \\
\hline Convertible & & & & $\begin{array}{l}0.007^{* * *} \\
(0.002) \\
{[0.14]}\end{array}$ & $\begin{array}{l}0.006^{* *} \\
(0.002) \\
{[0.13]}\end{array}$ & $\begin{array}{l}0.006^{\text {*** }} \\
(0.002) \\
{[0.14]}\end{array}$ \\
\hline dconv & & & & $\begin{array}{c}-0.522^{* * *} \\
(0.116)\end{array}$ & $\begin{array}{c}-0.492^{* * *} \\
(0.116)\end{array}$ & $\begin{array}{c}-0.500^{* * *} \\
(0.116)\end{array}$ \\
\hline Size & $\begin{array}{c}0.073 \\
(0.046)\end{array}$ & $\begin{array}{c}0.091^{*} \\
(0.047)\end{array}$ & $\begin{array}{c}0.081^{*} \\
(0.047)\end{array}$ & $\begin{array}{r}0.090^{*} \\
(0.047)\end{array}$ & $\begin{array}{r}0.080^{*} \\
(0.047)\end{array}$ & $\begin{array}{r}0.089^{*} \\
(0.047)\end{array}$ \\
\hline Log(book-to-market) & $\begin{array}{l}0.316^{* * *} \\
(0.108)\end{array}$ & $\begin{array}{c}0.360^{* * *} \\
(0.105)\end{array}$ & $\begin{array}{c}0.318^{* * *} \\
(0.108)\end{array}$ & $\begin{array}{l}0.373^{* * *} \\
(0.102)\end{array}$ & $\begin{array}{c}0.329^{* * *} \\
(0.105)\end{array}$ & $\begin{array}{c}0.333^{* * *} \\
(0.105)\end{array}$ \\
\hline Momentum & $\begin{array}{l}0.062^{* * *} \\
(0.020)\end{array}$ & $\begin{array}{c}0.064^{* * *} \\
(0.020)\end{array}$ & $\begin{array}{c}0.061^{* * *} \\
(0.020)\end{array}$ & $\begin{array}{c}0.064^{* * *} \\
(0.020)\end{array}$ & $\begin{array}{c}0.061^{* * *} \\
(0.020)\end{array}$ & $\begin{array}{c}0.060^{* * *} \\
(0.020)\end{array}$ \\
\hline Constant & $\begin{array}{r}-0.140 \\
(0.455)\end{array}$ & $\begin{array}{c}0.393 \\
(0.499)\end{array}$ & $\begin{array}{r}-0.231 \\
(0.450)\end{array}$ & $\begin{array}{c}0.474 \\
(0.500)\end{array}$ & $\begin{array}{r}-0.142 \\
(0.456)\end{array}$ & $\begin{array}{r}-0.239 \\
(0.449)\end{array}$ \\
\hline $\begin{array}{l}\text { Observations } \\
R^{2} \\
\text { Number of months }\end{array}$ & $\begin{array}{c}638,593 \\
0.03 \\
324\end{array}$ & $\begin{array}{c}638,593 \\
0.03 \\
324\end{array}$ & $\begin{array}{c}638,593 \\
0.03 \\
324\end{array}$ & $\begin{array}{c}638,593 \\
0.03 \\
324\end{array}$ & $\begin{array}{c}638,593 \\
0.03 \\
324\end{array}$ & $\begin{array}{c}638,593 \\
0.03 \\
324\end{array}$ \\
\hline
\end{tabular}

$(4)$

$(5)$

(6) 
Table 4: continued

\begin{tabular}{|c|c|c|c|c|c|c|}
\hline \multicolumn{7}{|c|}{ Panel B: Firms in the lowest or highest Z-score quartile } \\
\hline & \multicolumn{3}{|c|}{ Lowest Z-score quartile } & \multicolumn{3}{|c|}{ Highest Z-score quartile } \\
\hline & $(1)$ & $(2)$ & $(3)$ & $(4)$ & $(5)$ & $(6)$ \\
\hline \multirow[t]{3}{*}{ Shareholders } & $1.136^{* * *}$ & & $1.163^{* * *}$ & * $0.684^{*}$ & & $0.677^{*}$ \\
\hline & $(0.410)$ & & $(0.407)$ & $(0.409)$ & & $(0.411)$ \\
\hline & {$[0.24]$} & & {$[0.25]$} & {$[0.09]$} & & {$[0.10]$} \\
\hline \multirow[t]{3}{*}{ Secured } & & $0.002^{*}$ & $0.003^{* *}$ & & -0.001 & -0.001 \\
\hline & & $(0.001)$ & $(0.001)$ & & $(0.001)$ & $(0.001)$ \\
\hline & & {$[0.09]$} & {$[0.11]$} & & {$[0.02]$} & {$[0.03]$} \\
\hline \multirow[t]{2}{*}{ Size } & 0.025 & 0.043 & 0.035 & $0.132^{* * *}$ & * $0.157^{* * *}$ & * $0.128^{* * *}$ \\
\hline & $(0.062)$ & $(0.060)$ & $(0.064)$ & $(0.049)$ & $(0.046)$ & $(0.048)$ \\
\hline \multirow[t]{2}{*}{ Log(book-to-market) } & $0.222^{* *}$ & $0.264^{* *}$ & $0.210^{*}$ & $0.514^{* * *}$ & * $0.546^{* * *}$ & * $0.506^{* * *}$ \\
\hline & $(0.109)$ & $(0.104)$ & $(0.109)$ & $(0.145)$ & $(0.141)$ & $(0.143)$ \\
\hline \multirow[t]{2}{*}{ Momentum } & $0.073^{* * *}$ & $0.075^{* * *}$ & ${ }^{*} \quad 0.072^{* * *}$ & $* 0.054^{* *}$ & $0.060^{* *}$ & $0.056^{* *}$ \\
\hline & $(0.019)$ & $(0.019)$ & $(0.019)$ & $(0.027)$ & $(0.027)$ & $(0.027)$ \\
\hline \multirow[t]{2}{*}{ Constant } & -0.230 & 0.389 & -0.411 & -0.079 & 0.247 & -0.023 \\
\hline & $(0.527)$ & $(0.603)$ & $(0.534)$ & $(0.509)$ & $(0.449)$ & $(0.501)$ \\
\hline Observations & 155,229 & 155,229 & 155,229 & 155,200 & 155,200 & 155,200 \\
\hline$R^{2}$ & 0.04 & 0.04 & 0.04 & 0.04 & 0.04 & 0.05 \\
\hline Number of months & 324 & 324 & 324 & 324 & 324 & 324 \\
\hline
\end{tabular}


Table 5: Abnormal returns from factor models

This table reports calendar time portfolio abnormal returns. At the beginning of every calendar month, stocks are sorted into five quantiles based on Shareholders, Secured, or Convertible. For secured and convertible debt, firms are grouped conditional that a firm has secured or convertible debt outstanding, respectively. XRet is the return in excess of the risk free rate. Alpha is the intercept on a regression of monthly excess returns on explanatory variables, that include the monthly returns from Fama and French (1993) mimicking portfolios, the Carhart (1997) momentum factor, and the Pastor and Stambaugh (2003) liquidity factor. These alphas are computed using all individual stocks by quantile, or using equal- and value-weighted monthly portfolio returns by quantile. L/S is the alpha of a zero-cost portfolio of firms that holds the firms in the highest quantile and sells short the firms in the lowest quantile. $\mathrm{N} / \mathrm{month}$ is either the average number of observations per quantile or the number of months with portfolio returns. The sample period is 1985 to 2012. Please refer to Table 1 for a definition of the variables. $t$-statistics are shown below the coefficient estimates.

\begin{tabular}{|c|c|c|c|c|c|c|}
\hline Panel A: & areho & ders as a p & oxy for 1 & egotiatic & ictions & \\
\hline & & & owest Z-scc & re quartile & & \\
\hline & & Individ & aal stocks & & EW-Portfolio & VW-Portfolio \\
\hline Quantile & XRet & 3 -factor $\alpha$ & 4 -factor $\alpha$ & 5 -factor $\alpha$ & 5 -factor $\alpha$ & 5 -factor $\alpha$ \\
\hline 1 & $0.31 \%$ & $-0.35 \%$ & $-0.21 \%$ & $-0.28 \%$ & $-0.29 \%$ & $-0.34 \%$ \\
\hline (low) & $(2.93)$ & $(3.36)$ & $(1.98)$ & $(2.71)$ & $(1.41)$ & $(1.48)$ \\
\hline 2 & $0.70 \%$ & $-0.03 \%$ & $0.13 \%$ & $0.06 \%$ & $0.01 \%$ & $0.27 \%$ \\
\hline & $(7.54))$ & $(0.35)$ & $(1.50)$ & $(0.63)$ & $(0.03)$ & (1.68) \\
\hline 3 & $0.79 \%$ & $-0.02 \%$ & $0.12 \%$ & $0.06 \%$ & $-0.01 \%$ & $0.03 \%$ \\
\hline & $(8.46)$ & $(0.24)$ & $(1.39)$ & $(0.64)$ & $(0.03)$ & $(0.18)$ \\
\hline 4 & $0.75 \%$ & $-0.14 \%$ & $-0.01 \%$ & $-0.06 \%$ & $-0.04 \%$ & $-0.11 \%$ \\
\hline & $(7.32))$ & $(1.53)$ & $(0.05)$ & $(0.63)$ & $(0.33)$ & $(0.60)$ \\
\hline 5 & $1.13 \%$ & $0.24 \%$ & $0.46 \%$ & $0.42 \%$ & $0.45 \%$ & $0.30 \%$ \\
\hline (high) & $(9.19)$ & $(2.01)$ & $(3.83)$ & $(3.45)$ & $(1.78)$ & $(1.27)$ \\
\hline $\mathrm{L} / \mathrm{S}$ & $0.82 \%$ & $0.59 \%$ & $0.67 \%$ & $0.71 \%$ & $0.74 \%$ & $0.64 \%$ \\
\hline & $(7.64)$ & $(5.64)$ & $(6.29)$ & $(6.62)$ & $(2.27)$ & $(1.95)$ \\
\hline $\mathrm{N} /$ months & 30,980 & 30,980 & 30,980 & 30,980 & 324 & 324 \\
\hline & & & ghest Z-sc & ore quartile & & \\
\hline 1 & $-0.06 \%$ & $-0.50 \%$ & $-0.22 \%$ & $-0.23 \%$ & $-0.13 \%$ & $0.18 \%$ \\
\hline (low) & $(0.67)$ & $(5.37)$ & $(2.40)$ & $(2.39)$ & $(0.79)$ & $(0.88)$ \\
\hline 2 & $0.25 \%$ & $-0.23 \%$ & $-0.01 \%$ & $-0.02 \%$ & $0.04 \%$ & $0.24 \%$ \\
\hline & $(2.98)$ & $(2.96)$ & $(0.05)$ & $(0.22)$ & $(0.40)$ & $(1.91)$ \\
\hline 3 & $0.55 \%$ & $0.05 \%$ & $0.21 \%$ & $0.23 \%$ & $0.21 \%$ & $0.47 \%$ \\
\hline & $(6.77)$ & $(0.63)$ & $(2.78)$ & $(3.01)$ & $(2.14)$ & $(3.85)$ \\
\hline 4 & $0.55 \%$ & $-0.02 \%$ & $0.13 \%$ & $0.14 \%$ & $0.08 \%$ & $0.13 \%$ \\
\hline & $(6.68)$ & $(0.31)$ & $(1.76)$ & (1.78) & $(0.71)$ & $(0.95)$ \\
\hline 5 & $0.54 \%$ & $-0.06 \%$ & $0.12 \%$ & $0.12 \%$ & $0.13 \%$ & $0.36 \%$ \\
\hline (high) & $(6.05)$ & $(0.68)$ & $(1.45)$ & $(1.45)$ & $(0.99)$ & $(2.49)$ \\
\hline $\mathrm{L} / \mathrm{S}$ & $0.60 \%$ & $0.44 \%$ & $0.35 \%$ & $0.35 \%$ & $0.26 \%$ & $0.18 \%$ \\
\hline & $(6.14)$ & $(4.76)$ & $(3.69)$ & $(3.67)$ & $(1.23)$ & $(0.73)$ \\
\hline $\mathrm{N} /$ months & 31,090 & 31,090 & 31,090 & 31,090 & 324 & 324 \\
\hline
\end{tabular}


Table 5: continued

\begin{tabular}{|c|c|c|c|c|c|c|}
\hline \multicolumn{7}{|c|}{ Panel B: Proportion of secured debt } \\
\hline \multirow[b]{3}{*}{ Quantile } & \multicolumn{5}{|c|}{ Lowest Z-score quartile } & \multirow{3}{*}{$\begin{array}{c}\text { VW-Portfolio } \\
5 \text {-factor } \alpha\end{array}$} \\
\hline & \multicolumn{4}{|c|}{ Individual stocks } & \multirow{2}{*}{$\begin{array}{c}\text { EW-Portfolio } \\
5 \text {-factor } \alpha\end{array}$} & \\
\hline & XRet & 3 -factor $\alpha$ & 4 -factor $\alpha$ & 5 -factor $\alpha$ & & \\
\hline 1 & $0.65 \%$ & $-0.11 \%$ & $0.04 \%$ & $-0.04 \%$ & $-0.17 \%$ & $0.15 \%$ \\
\hline (low) & $(5.84)$ & $(1.06)$ & $(0.39)$ & $(0.35)$ & $(1.05)$ & $(0.86)$ \\
\hline \multirow[t]{2}{*}{2} & $0.72 \%$ & $-0.06 \%$ & $0.13 \%$ & $0.07 \%$ & $0.11 \%$ & $0.02 \%$ \\
\hline & $(6.10))$ & $(0.54)$ & $(1.16)$ & $(0.62)$ & $(0.64)$ & $(0.11)$ \\
\hline \multirow[t]{2}{*}{3} & $0.67 \%$ & $-0.15 \%$ & $0.03 \%$ & $-0.04 \%$ & $-0.08 \%$ & $0.15 \%$ \\
\hline & $(5.65)$ & $(1.41)$ & $(0.24)$ & $(0.38)$ & $(0.48)$ & $(0.68)$ \\
\hline \multirow[t]{2}{*}{4} & $0.74 \%$ & $-0.02 \%$ & $0.15 \%$ & $0.11 \%$ & $0.06 \%$ & $-0.03 \%$ \\
\hline & $(6.34)$ & $(0.19)$ & $(1.33)$ & (1.01) & $(0.33)$ & $(0.13)$ \\
\hline 5 & $0.98 \%$ & $0.14 \%$ & $0.27 \%$ & $0.19 \%$ & $0.21 \%$ & $0.35 \%$ \\
\hline (high) & $(8.43)$ & $(1.24)$ & $(2.40)$ & (1.68) & (1.13) & $(1.70)$ \\
\hline \multirow[t]{2}{*}{$\mathrm{L} / \mathrm{S}$} & $0.33 \%$ & $0.25 \%$ & $0.23 \%$ & $0.23 \%$ & $0.38 \%$ & $0.20 \%$ \\
\hline & $(2.88)$ & $(2.35)$ & $(2.12)$ & $(2.10)$ & $(1.55)$ & $(0.72)$ \\
\hline $\mathrm{N} /$ months & 25,150 & 25,150 & 25,150 & 25,150 & 324 & 324 \\
\hline
\end{tabular}

Highest Z-score quartile

\begin{tabular}{lcccccc}
\hline 1 & $0.50 \%$ & $0.05 \%$ & $0.21 \%$ & $0.20 \%$ & $0.20 \%$ & $0.26 \%$ \\
$($ low $)$ & $(5.18)$ & $(0.55)$ & $(2.30)$ & $(2.20)$ & $(1.85)$ & $(2.02)$ \\
2 & $0.40 \%$ & $-0.07 \%$ & $0.19 \%$ & $0.19 \%$ & $0.17 \%$ & $0.14 \%$ \\
& $(3.60)$ & $(0.71)$ & $(1.83)$ & $(1.80)$ & $(1.35)$ & $(0.73)$ \\
3 & $0.21 \%$ & $-0.31 \%$ & $-0.09 \%$ & $-0.07 \%$ & -0.09 & $0.23 \%$ \\
& $(1.78)$ & $(2.89)$ & $(0.9)$ & $(0.69)$ & $(0.63)$ & $(1.09)$ \\
4 & $0.25 \%$ & $-0.22 \%$ & $0.02 \%$ & $0.01 \%$ & $0.04 \%$ & $0.25 \%$ \\
& $(2.23)$ & $(2.10)$ & $(0.16)$ & $(0.09)$ & $(0.30)$ & $(1.20)$ \\
5 & $0.23 \%$ & $-0.32 \%$ & $-0.16 \%$ & $-0.13 \%$ & $-0.08 \%$ & $0.46 \%$ \\
(high) & $(2.19)$ & $(3.31)$ & $(1.64)$ & $(1.38)$ & $(0.66)$ & $(2.26)$ \\
L/S & $-0.28 \%$ & $-0.37 \%$ & $-0.37 \%$ & $-0.34 \%$ & $-0.28 \%$ & $0.20 \%$ \\
& $(2.83)$ & $(4.08)$ & $(4.04)$ & $(3.65)$ & $(1.72)$ & $(0.87)$ \\
N/months & 21,292 & 21,292 & 21,292 & 21,292 & 324 & 324 \\
\hline
\end{tabular}


Table 5: continued

\begin{tabular}{lcccccc}
\hline Panel C: Proportion of convertible debt \\
\hline \multicolumn{7}{c}{ Full sample } \\
Quantile & XRet & Individual stocks & & EW-Portfolio & VW-Portfolio \\
\hline 1 & $0.52 \%$ & $-0.26 \%$ & $-0.12 \%$ & $-0.14 \%$ & $-0.14 \%$ & $0.07 \%$ \\
(low) & $(4.66)$ & $(2.49)$ & $(1.09)$ & $(1.28)$ & $(0.96)$ & $(0.49)$ \\
2 & $0.32 \%$ & $-0.41 \%$ & $-0.24 \%$ & $-0.30 \%$ & $-0.30 \%$ & $-0.18 \%$ \\
& $(2.86)$ & $(3.93)$ & $(2.31)$ & $(2.80)$ & $(2.01)$ & $(1.04)$ \\
3 & $0.31 \%$ & $-0.40 \%$ & $-0.24 \%$ & $-0.29 \%$ & $-0.21 \%$ & $-0.14 \%$ \\
& $(2.69)$ & $(3.68)$ & $(2.19)$ & $(2.63)$ & $(1.45)$ & $(0.75)$ \\
4 & $0.31 \%$ & $-0.34 \%$ & $-0.14 \%$ & $-0.21 \%$ & $-0.21 \%$ & $0.23 \%$ \\
& $(2.60)$ & $(3.10)$ & $(1.23)$ & $(1.85)$ & $(1.28)$ & $(1.15)$ \\
5 & $0.72 \%$ & $0.06 \%$ & $0.29 \%$ & $0.32 \%$ & $0.34 \%$ & $0.75 \%$ \\
(high) & $(5.88)$ & $(0.54)$ & $(2.54)$ & $(2.78)$ & $(1.93)$ & $(3.20)$ \\
L/S & $0.20 \%$ & $0.32 \%$ & $0.40 \%$ & $0.45 \%$ & $0.48 \%$ & $0.68 \%$ \\
& $(1.73)$ & $(3.02)$ & $(3.74)$ & $(4.18)$ & $(2.10)$ & $(2.43)$ \\
N/months & 19,034 & 19,034 & 19,034 & 19,034 & 324 & 324 \\
\hline
\end{tabular}


Table 6: Instrumental variable regressionst

This table presents the first and second stage estimates from instrumental variable regressions. The dependent variable in columns 2,4 , and 7 is the monthly stock return. Shareholders is the normalized number of institutional shareholders, Secured is the proportion of secured to total debt, Convertible is the proportion of convertible to total debt, and dconv is a dummy equal to one if the firm has convertible debt, zero otherwise. The sample period is 1985 to 2012. Please refer to Table 1 for a definition of the variables. The instruments for secured debt are a utility industry dummy and one year lagged secured debt. The instruments for convertible debt are a utility industry dummy, one year lagged convertible debt, and the presence of a credit rating. The Sargan chi2-statistic of overidentifying restrictions and its p-values are presented at the bottom of the table. All specifications include monthly dummies. Robust standard errors are reported in parentheses below the coefficient estimates. Coefficients marked ***, **, and * are significant at the $1 \%, 5 \%$, and $10 \%$ significance level, respectively.

\begin{tabular}{|c|c|c|c|c|c|c|c|}
\hline & $\begin{array}{l}\text { 1. Z-score } \\
(1) \\
\text { 1. stage } \\
\text { Secured }\end{array}$ & $\begin{array}{l}\text { quartile } \\
(2) \\
2 . \text { stage }\end{array}$ & $\begin{array}{l}\text { 4. Z-score } \\
(3) \\
\text { 1. stage } \\
\text { Secured }\end{array}$ & $\begin{array}{l}\text { quartile } \\
\text { (4) stage }\end{array}$ & $\begin{array}{c}\text { Full } \\
\text { (5) } \\
\text { 1. stage } \\
\text { Convertible }\end{array}$ & $\begin{array}{l}\text { sample } \\
(6) \\
\text { 1. stage } \\
\text { dconv }\end{array}$ & $\begin{array}{l}(7) \\
\text { 2. stage }\end{array}$ \\
\hline Secured & & $\begin{array}{l}0.005^{* * *} \\
(0.002)\end{array}$ & & $\begin{array}{l}-0.001 \\
(0.001)\end{array}$ & & & \\
\hline $\begin{array}{l}\text { Convertible } \\
\text { dconv }\end{array}$ & & & & & & & $\begin{array}{c}0.042^{* * *} \\
(0.009) \\
-3.223^{* * *} \\
(0.654)\end{array}$ \\
\hline Shareholders & $\begin{array}{l}-2.888^{* * *} \\
(0.339)\end{array}$ & $\begin{array}{l}1.167^{* * *} \\
(0.228)\end{array}$ & * $\begin{array}{c}0.023 \\
(0.550)\end{array}$ & $\begin{array}{c}0.114 \\
(0.303)\end{array}$ & $\begin{array}{l}3.309^{* * *} \\
(0.131)\end{array}$ & $\begin{array}{c}0.005^{* *} \\
(0.003)\end{array}$ & $\begin{array}{l}0.821^{* * *} \\
(0.140)\end{array}$ \\
\hline Size & $\begin{array}{l}-0.919^{* * *} \\
(0.036)\end{array}$ & $\begin{array}{l}0.084^{* * *} \\
(0.024)\end{array}$ & $\begin{array}{c}* 1.551^{* * *} \\
(0.043)\end{array}$ & $\begin{array}{l}0.150^{* * *} \\
(0.024)\end{array}$ & $\begin{array}{l}-0.283^{* * *} \\
(0.013)\end{array}$ & $\begin{array}{c}-0.003^{* * *} \\
(0.001)\end{array}$ & $\begin{array}{l}0.106^{* * *} \\
(0.014)\end{array}$ \\
\hline Log(book-to-market) & $\begin{array}{l}1.376^{* * *} \\
(0.076)\end{array}$ & $\begin{array}{l}0.282^{* * *} \\
(0.051)\end{array}$ & $\begin{array}{c}{ }^{*}-0.248^{* *} \\
(0.107)\end{array}$ & $\begin{array}{l}0.591^{* * *} \\
(0.059)\end{array}$ & $\begin{array}{l}-1.467^{* * *} \\
(0.027)\end{array}$ & $\begin{array}{l}0.009^{* * *} \\
(0.001)\end{array}$ & $\begin{array}{l}0.477^{* * *} \\
(0.038)\end{array}$ \\
\hline Momentum & $\begin{array}{l}0.037^{* * *} \\
(0.012)\end{array}$ & $\begin{array}{l}0.067^{* * *} \\
(0.008)\end{array}$ & $\begin{array}{l}0.151^{* * *} \\
(0.017)\end{array}$ & $\begin{array}{c}0.012 \\
(0.009)\end{array}$ & $\begin{array}{c}-0.009^{* *} \\
(0.004)\end{array}$ & $\begin{array}{l}-0.001^{* * *} \\
(0.000)\end{array}$ & $\begin{array}{l}0.047^{* * *} \\
(0.005)\end{array}$ \\
\hline Utility dummy & $\begin{array}{l}0.895^{* * *} \\
(0.322)\end{array}$ & & $\begin{array}{c}-2.303^{* *} \\
(1.170)\end{array}$ & & $\begin{array}{c}-0.165 \\
(0.149)\end{array}$ & $\begin{array}{l}0.062^{* * *} \\
(0.003)\end{array}$ & \\
\hline Lagged Secured & $\begin{array}{l}0.711^{* * *} \\
(0.002)\end{array}$ & & $\begin{array}{l}0.733^{* * *} \\
(0.002)\end{array}$ & & & & \\
\hline Lagged Convertible & & & & & $\begin{array}{l}0.801^{* * *} \\
(0.001)\end{array}$ & $\begin{array}{l}0.011^{* * *} \\
(0.000)\end{array}$ & \\
\hline Credit rating & & & & & $\begin{array}{l}2.180^{* * *} \\
(0.054)\end{array}$ & $\begin{array}{l}0.110^{* * *} \\
(0.001)\end{array}$ & \\
\hline Monthly dummies & yes & yes & yes & yes & yes & yes & yes \\
\hline Observations & 139,860 & 139,860 & 127,829 & 127,829 & 503,374 & 503,374 & 503,374 \\
\hline Adjusted $R^{2}$ & 0.54 & 0.13 & 0.58 & 0.17 & 0.64 & 0.46 & 0.14 \\
\hline $\begin{array}{l}\text { Sargan chi2-statistic } \\
\text { p-value (chi2) }\end{array}$ & & $\begin{array}{l}0.37 \\
0.55\end{array}$ & & $\begin{array}{l}0.43 \\
0.51\end{array}$ & & & $\begin{array}{l}2.12 \\
0.15\end{array}$ \\
\hline
\end{tabular}




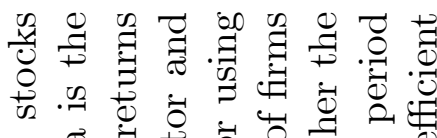

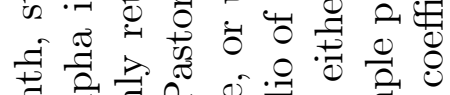

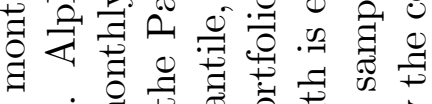

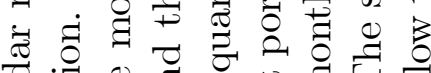

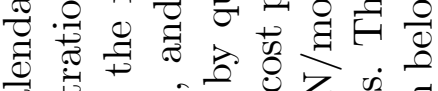

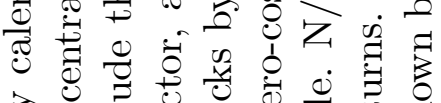

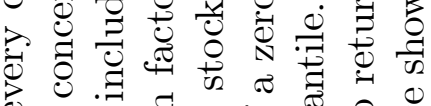

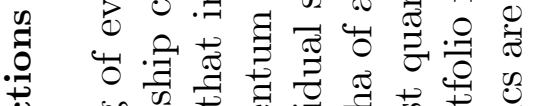

至 然

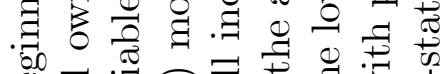

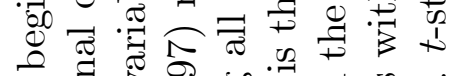
o

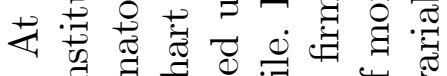

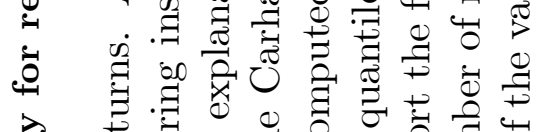

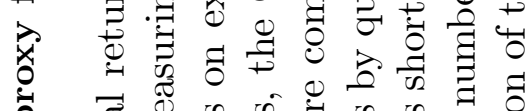

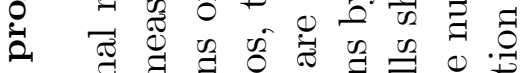

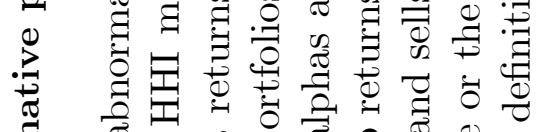
等

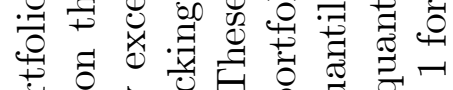

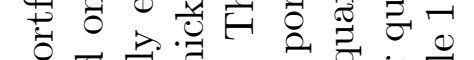

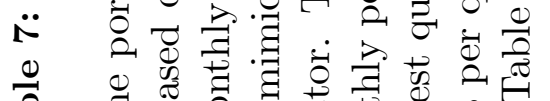

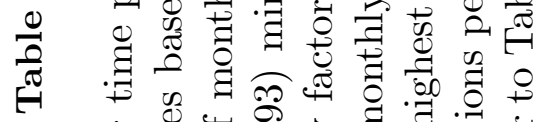

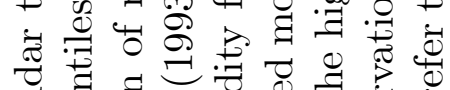

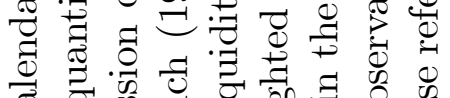
덩

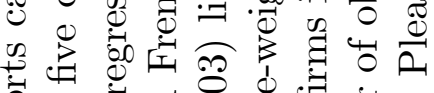

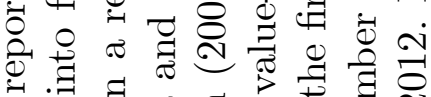

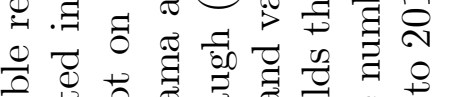

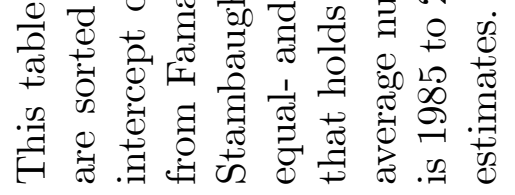

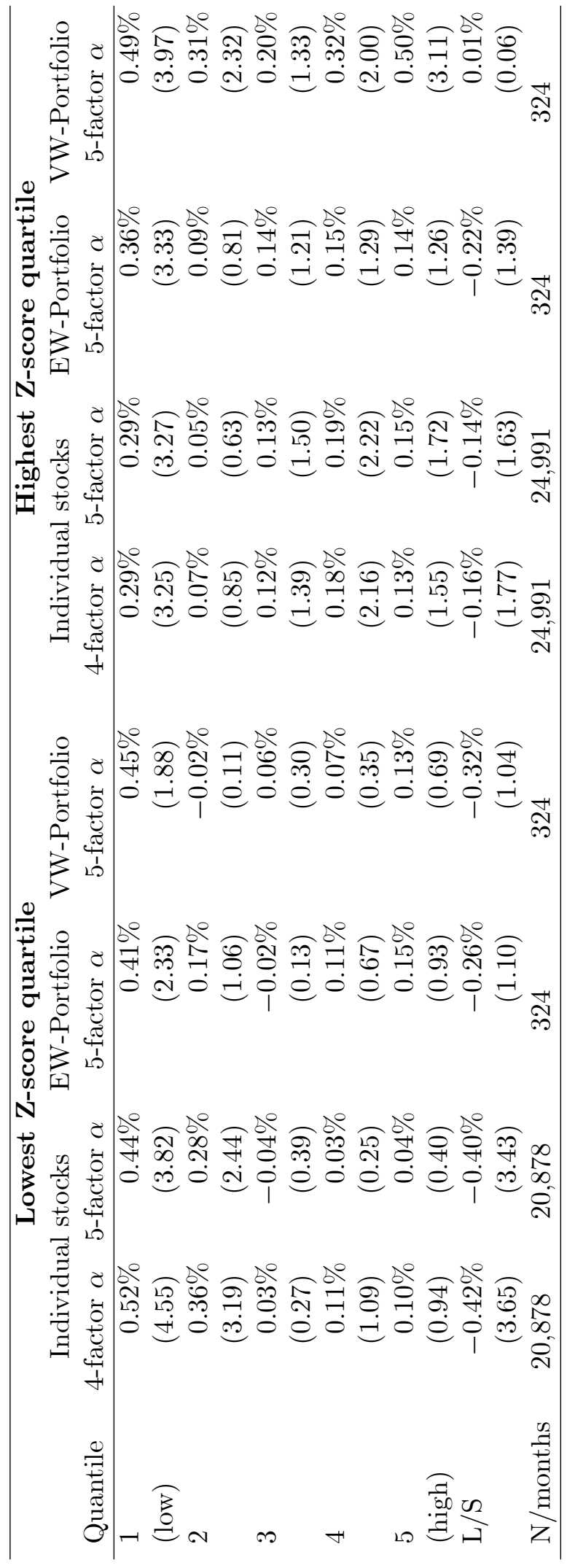


Table 8: Renegotiation frictions and distress premia around Chapter 11 filings

This table reports calendar time abnormal returns for firms that filed for Chapter 11. For a maximum of five years before to three years after the filing, stocks are sorted, at the beginning of every calendar month, into two groups based on the median time a firm has spent in Chapter 11. In addition, each of these two groups is split into two groups based on the median of Shareholders. Alpha is the intercept on a regression of monthly excess returns on explanatory variables, that include the monthly returns from Fama and French (1993) mimicking portfolios, the Carhart (1997) momentum factor, and the Pastor and Stambaugh (2003) liquidity factor. These alphas are computed using all individual stocks by quantile, or using equal- and value-weighted monthly portfolio returns by quantile. L/S is the alpha of a zero-cost portfolio of firms that holds the firms in the highest quantile and sells short the firms in the lowest quantile. $\mathrm{N} /$ month is either the average number of observations per quantile or the number of months with portfolio returns. The sample period is 1985 to 2012 . Please refer to Table 1 for a definition of the variables. $t$-statistics are shown below the coefficient estimates.

\begin{tabular}{lcccccc}
\hline & \multicolumn{3}{c}{ Long bankruptcies } & \multicolumn{3}{c}{ Short bankruptcies } \\
& Ind. stocks & EW-Portf. & VW-Portf. & Ind. stocks & EW-Portf. & VW-Portf. \\
& 5 -factor $\alpha$ & 5 -factor $\alpha$ & 5 -factor $\alpha$ & 5 -factor $\alpha$ & 5 -factor $\alpha$ & 5 -factor $\alpha$ \\
\hline Below median & $-3.36 \%$ & $-4.21 \%$ & $-6.40 \%$ & $-3.73 \%$ & $-4.87 \%$ & $-4.83 \%$ \\
& $(10.96)$ & $(3.32)$ & $(4.05)$ & $(11.05)$ & $(4.09)$ & $(2.74)$ \\
Above median & $-2.82 \%$ & $-2.72 \%$ & $-3.47 \%$ & $-3.58 \%$ & $-2.56 \%$ & $-1.09 \%$ \\
& $(9.16)$ & $(2.39)$ & $(2.62)$ & $(10.84)$ & $(3.20)$ & $(0.95)$ \\
L/S & $0.53 \%$ & $1.49 \%$ & $2.93 \%$ & $0.15 \%$ & $2.31 \%$ & $3.74 \%$ \\
& $(1.74)$ & $(0.87)$ & $(1.42)$ & $(0.43)$ & $(1.65)$ & $(1.78)$ \\
$\mathrm{N} /$ months & 3,660 & 97 & 97 & 3,645 & 97 & 97 \\
\hline
\end{tabular}


Table 9: Alternative proxies for distress

This table reports calendar time portfolio abnormal returns from a 5-factor $\alpha$ model. At the beginning of every calendar month, stocks are sorted into five quantiles based on Shareholders or Secured. For secured debt, firms are grouped conditional that a firm has secured debt outstanding. The 5-factor $\alpha$ is the intercept on a regression of monthly excess returns on explanatory variables, that include the monthly returns from Fama and French (1993) mimicking portfolios, the Carhart (1997) momentum factor, and the Pastor and Stambaugh (2003) liquidity factor. These alphas are computed using all individual stocks by quantile, or using equal- and value-weighted monthly portfolio returns by quantile. L/S is the alpha of a zero-cost portfolio of firms that holds the firms in the highest quantile and sells short the firms in the lowest quantile. $\mathrm{N} /$ month is either the average number of observations per quantile or the number of months with portfolio returns. The sample period is 1985 to 2012 . Please refer to Table 1 for a definition of the variables. $t$-statistics are shown below the coefficient estimates.

\begin{tabular}{|c|c|c|c|c|c|c|}
\hline \multicolumn{7}{|c|}{ Panel A: Zmijewski score } \\
\hline \multicolumn{7}{|l|}{ Shareholders } \\
\hline \multirow[b]{2}{*}{ Quantile } & \multicolumn{3}{|c|}{ Above median Zmijewski score } & \multicolumn{3}{|c|}{ Below median Zmijewski score } \\
\hline & Ind. stocks & EW-Portf. & VW-Portf. & Ind. stocks & EW-Portf. & VW-Portf. \\
\hline 1 & $-0.25 \%$ & $-0.30 \%$ & $-0.09 \%$ & $0.06 \%$ & $0.06 \%$ & $0.10 \%$ \\
\hline (low) & $(3.52)$ & $(1.76)$ & $(0.48)$ & $(1.04)$ & $(0.38)$ & $(0.61)$ \\
\hline 5 & $0.32 \%$ & $0.28 \%$ & $0.31 \%$ & $0.39 \%$ & $0.46 \%$ & $0.38 \%$ \\
\hline (high) & $(4.19)$ & $(1.51)$ & $(1.94)$ & $(6.27)$ & $(3.65)$ & $(2.29)$ \\
\hline $\mathrm{L} / \mathrm{S}$ & $0.57 \%$ & $0.58 \%$ & $0.40 \%$ & $0.33 \%$ & $0.40 \%$ & $0.28 \%$ \\
\hline & $(8.02)$ & $(2.30)$ & $(1.67)$ & $(5.22)$ & $(2.07)$ & $(1.36)$ \\
\hline $\mathrm{N} /$ months & 62,070 & 324 & 324 & 62010 & 324 & 324 \\
\hline
\end{tabular}

\begin{tabular}{lcccccc}
\hline Secured & \multicolumn{3}{c}{ Above median Zmijewski score } & \multicolumn{3}{c}{ Below median Zmijewski score } \\
Quantile & Ind. stocks & EW-Portf. & VW-Portf. & Ind. stocks & EW-Portf. & VW-Portf. \\
\hline 1 & $0.11 \%$ & $0.03 \%$ & $0.28 \%$ & $0.14 \%$ & $0.14 \%$ & $0.24 \%$ \\
(low) & $(1.65)$ & $(0.35)$ & $(2.66)$ & $(2.28)$ & $(1.56)$ & $(2.25)$ \\
5 & $0.20 \%$ & $0.13 \%$ & $0.43 \%$ & $0.14 \%$ & $0.14 \%$ & $0.37 \%$ \\
(high) & $(2.57)$ & $(0.90)$ & $(2.44)$ & $(1.92)$ & $(1.18)$ & $(2.08)$ \\
L/S & $0.09 \%$ & $0.10 \%$ & $0.15 \%$ & $0.00 \%$ & $0.00 \%$ & $0.13 \%$ \\
& $(1.31)$ & $(0.54)$ & $(0.71)$ & $(0.01)$ & $(0.04)$ & $(0.61)$ \\
N/months & 48,380 & 324 & 324 & $43,388]$ & 324 & 324 \\
\hline
\end{tabular}




\section{Table 9: continued}

\begin{tabular}{|c|c|c|c|c|c|c|}
\hline \multicolumn{7}{|c|}{ Panel B: Default probability } \\
\hline \multicolumn{7}{|l|}{ Shareholders } \\
\hline \multirow[b]{2}{*}{ Quantile } & \multicolumn{3}{|c|}{ Above median Default Probability } & \multicolumn{3}{|c|}{ Below median Default Probability } \\
\hline & Ind. stocks & EW-Portf. & VW-Portf. & Ind. stocks & EW-Portf. & VW-Portf. \\
\hline 1 & $-0.19 \%$ & $-0.18 \%$ & $-0.21 \%$ & $0.01 \%$ & $-0.02 \%$ & $-0.07 \%$ \\
\hline (low) & $(3.55)$ & $(1.10)$ & $(1.08)$ & $(0.11)$ & $(0.11)$ & $(0.44)$ \\
\hline 5 & $0.27 \%$ & $0.29 \%$ & $0.46 \%$ & $0.44 \%$ & $0.44 \%$ & $0.33 \%$ \\
\hline (high) & $(3.55)$ & $(1.65)$ & $(2.84)$ & $(7.00)$ & $(3.43)$ & $(2.37)$ \\
\hline $\mathrm{L} / \mathrm{S}$ & $0.46 \%$ & $0.47 \%$ & $0.66 \%$ & $0.43 \%$ & $0.46 \%$ & $0.40 \%$ \\
\hline & $(6.68)$ & $(1.96)$ & $(2.65)$ & $(6.82)$ & $(2.37)$ & $(1.95)$ \\
\hline $\mathrm{N} /$ months & 62,270 & 324 & 324 & 62,340 & 324 & 324 \\
\hline
\end{tabular}

\begin{tabular}{|c|c|c|c|c|c|c|}
\hline \multicolumn{7}{|l|}{ Secured } \\
\hline \multirow[b]{2}{*}{ Quantile } & \multicolumn{3}{|c|}{ Above median Default Probability } & \multicolumn{3}{|c|}{ Below median Default Probability } \\
\hline & Ind. stocks & EW-Portf. & VW-Portf. & Ind. stocks & EW-Portf. & VW-Portf. \\
\hline 1 & $-0.04 \%$ & $-0.09 \%$ & $0.20 \%$ & $0.10 \%$ & $0.06 \%$ & $0.26 \%$ \\
\hline (low) & $(0.58)$ & $(0.71)$ & $(1.51)$ & $(1.69)$ & $(0.56)$ & $(2.19)$ \\
\hline 5 & $0.02 \%$ & $0.09 \%$ & $0.35 \%$ & $0.24 \%$ & $0.16 \%$ & $0.47 \%$ \\
\hline (high) & $(0.31)$ & $(0.59)$ & $(2.19)$ & $(3.55)$ & $(1.44)$ & $(2.48)$ \\
\hline $\mathrm{L} / \mathrm{S}$ & $0.06 \%$ & $0.18 \%$ & $0.15 \%$ & $0.14 \%$ & $0.10 \%$ & $0.21 \%$ \\
\hline & $(0.93)$ & $(0.91)$ & $(0.72)$ & $(2.48)$ & $(0.68)$ & $(0.92)$ \\
\hline $\mathrm{N} /$ months & 48,330 & 324 & 324 & 43,860 & 324 & 324 \\
\hline
\end{tabular}




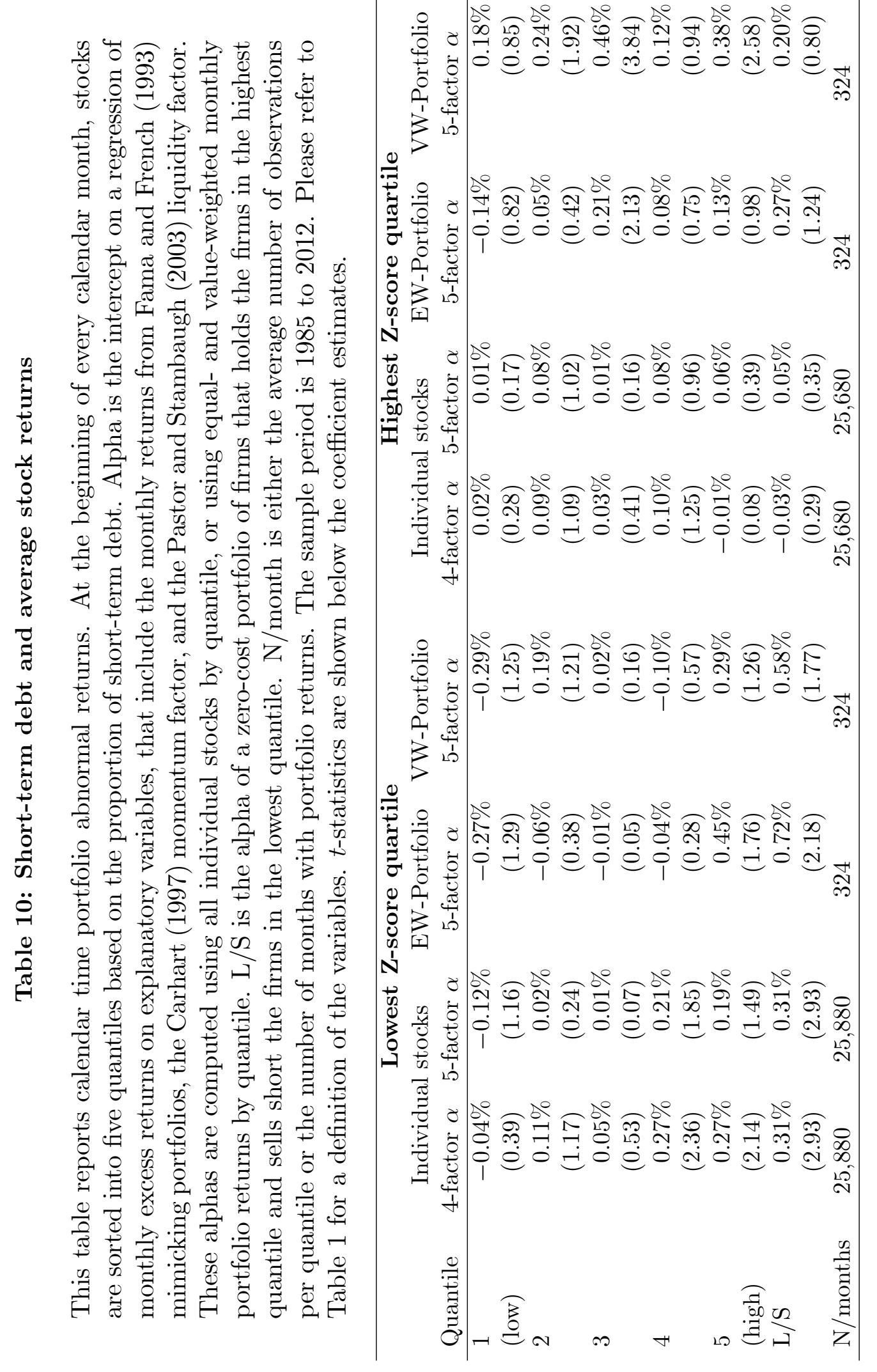




\section{References}

Altman, E.. "Financial Ratios, Discriminant Analysis and the Prediction of Corporate Bankruptcy." Journal of Finance, 23 (1968), 589-609.

Anderson, R., and S. Sundaresan. "The Design and Valuation of Debt Contracts." Review of Financial Studies, 9 (1996), 37-68.

Angrist, J., and J.-S. Pischke. "Mostly Harmless Econometrics: An Empiricist's Companion." Princeton University Press (2009).

Asquith, P., R. Gertner, and D. Scharfstein. "Anatomy of Financial Distress: An Examination of Junk-Bond Issues." Quarterly Journal of Economics, 109 (1994), 625-658.

Baldwin, C., and S. Mason. "The Priority Structure of Corporate Liabilities." Journal of Finance, 50 (1995), 899-917.

Barclay, M., and C. Smith. "The Priority Structure of Corporate Liabilities." Journal of Finance, 50 (1995), 899-917.

Bharath, S., and T. Shumway. "Forecasting Default with the Merton Distance to Default Model." Review of Financial Studies, 21 (2008), 1339-1369.

Berglof, E., and E. von Thadden. "Short-term versus long-term interests: Capital structure with multiple investors." Quarterly Journal of Economics, 109 (1994), 1055-1084.

Bolton, P., and D. Scharfstein. "Optimal Debt Structure and the Number of Creditors." Journal of Political Economy, 104 (1996), 1-25.

Bris, A., I. Welch, and N. Zhu. "The Costs of Bankruptcy: Chapter 7 Liquidation versus Chapter 11 Reorganization." Journal of Finance, 61 (2006), 1253-1303.

Carhart, M.. "On the Persistence in Mutual Fund Performance." Journal of Finance, 52 (1997), 57-82.

Colla, P., F. Ippolito, and K. Li. "Debt Specialization." Journal of Finance, 68 (2013), 2117-2141. 
Davydenko, S., and I. Strebulaev. "Strategic Actions and Credit Spreads: An Empirical Investigation." Journal of Finance, 62, (2007), 2633-2671.

Fama, E., and K. French. "The Cross-section of Expected Stock Returns." Journal of Finance, 47 (1992), 427-465.

Fama, E., and K. French. "Common Risk Factors in the Returns of Stocks and Bonds." Journal of Financial Economics, 33 (1993), 3-56.

Fama, E., and J. MacBeth. "Risk, Return, and Equilibrium: Empirical Tests." Journal of Political Economy, 81 (1973), 607-636.

Fan, H., and S. Sundaresan. "Debt Valuation, Renegotiation, and Optimal Dividend Policy." Review of Financial Studies, 13 (2000), 1057-1099.

Faulkender, M., and M. Petersen. "Does the Source of Capital Affect Capital Structure." Review of Financial Studies, 19 (2006), 45-79.

Favara, G., E. Schroth, and P. Valta. "Strategic Default and Equity Risk Across Countries." Journal of Finance, 67 (2012), 2051-2095. 1057-1099.

Franks, J., and W. Torous. "An Empirical Investigation of U.S. Firms in Reorganization." Journal of Finance, 44 (1989), 747-769.

Francois, P., and E. Morellec. "Capital Structure and Asset Prices: Some Effects of Bankruptcy Procedures." Journal of Business, 77 (2004), 387-411.

Garlappi, L., T. Shu, and H. Yan. "Default Risk, Shareholder Advantage, and Stock Returns." Review of Financial Studies, 21 (2008), 2743-2778.

Garlappi, L., and H. Yan. "Financial Distress and the Cross-section of Equity Returns." Journal of Finance, 66 (2011), 789-822.

Gertner, R., and D. Scharfstein. "A Theory of Workouts and the Effects of Reorganization Law." Journal of Finance, 46 (1991), 1189-1222. 
Gilson, S., K. John, and L. Lang. "Troubled Debt Restructuring: An Empirical Study of Private Reorganization of Firms in Default." Journal of Financial Economics, 27 (1990), 315-353.

Hackbarth, D., R. Haselmann, and D. Schoenherr. "Distress Risk, Stock Returns, and the 1978 Bankruptcy Reform Act." Working paper (2013), Boston University.

Hackbarth, D., C. Hennessy, and H. Leland. "Can the Trade-Off Theory Explain Debt Structure?" Review of Financial Studies, 20 (2007), 1389-1428.

Hege, U., and P. Mella-Barral. "Repeated Dilution of Diffusely Held Debt." Journal of Business, 78 (2005), 737-786.

Hennessy, C., and Y. Tserlukevich. "Taxation, Agency Conflicts, and the Choice Between Callable and Convertible Debt." Journal of Economic Theory, 143 (2008), 374-404.

Houston, J., and C. James. "Bank Information Monopolies and the Mix of Private and Public Debt Claims." Journal of Finance, 51 (1996), 1863-1889.

Ingersoll, J.. "A Contingent-Claims Valuation of Convertible Securities." Journal of Financial Economics, 4 (1977), 289-321.

Jensen, M., and W. Meckling. "Theory of the Firm: Managerial Behavior, Agency Costs, and Capital Structure." Journal of Financial Economics, 3 (1976), 305-360.

Johnson, H., and R. Stulz. "An Analysis of Secured Debt." Journal of Financial Economics, 14 (1985), 501-521.

Leeth, J., and J. Scott. "The Incidence of Secured Debt: Evidence from the Small Business Community." Journal of Financial and Quantitative Analysis, 24 (1989), 379-394.

Lyandres, E., and A. Zhdanov. "Convertible Debt and Investment Timing." Journal of Corporate Finance, forthcoming (2013).

Mayers, D.. "Why Firms Issue Convertible Bonds: The Matching of Financial and Real Investment Options." Journal of Financial Economics, 47 (1998), 83-102. 
Mella-Barral, P., and W. Perraudin. "Strategic Debt Service." Journal of Finance, 52 (1997), $531-556$.

Mikkelson, W.. "Convertible Debt and Security Returns." Journal of Financial Economics, 9 (1981), 237-264.

Morellec, E.. "Asset Liquidity, Capital Structure, and Secured Debt." Journal of Financial Economics, 61 (2001), 173-206.

Newey, W., and K. West. "A Simple, Positive Semi-Definite, Heteroskedasticity and Autocorrelation Consistent Covariance Matrix." Econometrica, 55 (1987), 703-708.

Pastor, L., and R. Stambaugh. "Liquidity Risk and Expected Stock Returns." Journal of Political Economy, 111 (2003), 642-685.

Rampini, A., and S. Viswanathan. "Collateral and Capital Structure." Journal of Financial Economics, 109 (2013), 466-492.

Rauh, J., and A. Sufi. "Capital Structure and Debt Structure." Review of Financial Studies, 12 (2010), 4242-4280.

Scott, J.. "Bankruptcy, Secured Debt, and Optimal Capital Structure." Journal of Finance, 32 (1977), 1-19.

Scott, J.. "Bankruptcy, Secured Debt, and Optimal Capital Structure: Reply." Journal of Finance, 34 (1979), 253-260.

Smith, C., and J. Warner. "On Financial Contracting: An Analysis of Bond Covenants." Journal of Financial Economics, 7 (1979), 117-161.

Stein, J.. "Convertible Bonds as Backdoor Financing." Journal of Financial Economics, 32 (1992), 3-21.

Vassalou, M., and Y. Xing. "Default Risk in Equity Returns." Journal of Finance, 59 (2004), 831-868. 
Zhang, A.. "Distress Risk Premia in Expected Stock and Bond Returns." Journal of Banking and Finance, 36 (2012), 225-238.

Zmijewski, M.. "Methological Issues Related to the Estimation of Financial Distress Prediction Models." Journal of Accounting Research, 22 (1984), 59-82. 